\title{
A thematic content analysis of rhetorical and dialectical argumentation studies in science education
}

\author{
Burçin Kahraman, Ministry of National Education, Turkey, burcinkahraman.deu@gmail.com \\ ORCID: 0000-0001-6307-3205
}

Osman Nafiz Kaya, Uşak University, Turkey, osmannafiz.kaya@usak.edu.tr ORCID:0000-0002-7736-2179

\begin{abstract}
The aim of this study was to investigate the studies of rhetoric and dialectical argumentation stuides published in four leading academic journals in the field of science education through thematic content analysis method. For this purpose, 34 articles, which are in accordance with the examination criteria, were determinedby content analysis method. The studies were examined considering the following themes: "aim", "features of sample", "subject", "data collection and analysis method", "argumentation process", and "result". Results revealed that majority of the studies were conducted according to rhetorical argumentation $(\mathrm{n}=26, \% 76)$ and that the studies with dialectic argumentation ( $n=8, \% 24$ ) were fewer. Moreover, it has been shown that the mostof studies were conducted to analyze student argumentation and to improve students' argumentation skills. It was seen that the sample size is usuallysmallin the argumentation studies. In addition, it was determined that the qualitative and mixed methods were mostly used in the studies and argumentation was mostly applied on science topics and concepts rather than socioscientific issues. Results showed that various rubrics or argumentative indicators were used to evaluate the argumentation process in most of the studies. In addition, in some rhetorical studies, it has been observed that new argumentation elements are added to adapt argumentation models to science education. It is suggested that in the future studies, dialectical argumentation studies that determine the role of teacher in the argumentation process and studies on the socioscientific topics with larger samples will fill the gap in this area.
\end{abstract}

Keywords: Argumentation, rhetorical argumentation, dialectical argumentation, science education, thematic content analysis

$\begin{array}{lll}\text { Received: } 13.05 .2019 & \text { Accepted: 29.06.2020 Published: 15.01.2020 }\end{array}$

\section{INTRODUCTION}

Argumentation is a cognitive process frequently used by scientists, engineers, lawyers, etc. The use of argumentation as a teaching method, especially in science classes, is recommended by many researchers (Berland \& Reiser, 2009; Clark \& Sampson, 2007; Driver, Newton \& Osborne, 2000; Erduran, Simon \& Osborne, 2004) and various international educational institutions and programs (American Association for the Advancement of Science [AAAS] 1990; Ministry of National Education [MNE] 2005; 2013; 2018; National Research Council [NRC] 2012; Next Generation Science Standards [NGSS] 2013). For this reason, the number of studies on the integration of argumentation in science education has increased very rapidly in recent years (Bağ \& Çalık, 2017). In this context, determining the purpose of argumentation, how it is implemented and what results have been achieved in science education studies conducted so far will guide future studies. In this study, rhetorical and dialectical argumentation studies conducted in science education were examined comparatively with the thematic content analysis method.

\section{Science Education and Argumentation}

Argumentation has started to be used as a teaching method in science education in the last 30 years and its use continues to increase (Aktamış \& Hiğde, 2015). Toulmin model has been the most used argumentation model in science education (Bağ \& Çalık, 2017; Nielsen, 2013). According to Toulmin, argumentation is the process of structuring appropriate rationales that 
relate claims to the data on which they are based (Toulmin, 1958). Kuhn (1992) defined argumentation as a process of sharing, supporting, criticizing and evaluating a scientific subject while van Eemeren, Grootendorst, Henkemans, Blair, Johnson, Krabbe, Plantin, Walton, Willard, Woods and Zarefsky (1996) stated that argumentation was complex speech actions aimed at solving the difference of opinion. Based on these definitions, it can be said that argumentation is a social process that improves scientific thinking and reasoning processes of individual.

Studies show that individuals often confuse argumentation and discussion. Discussion and argumentation are different concepts. While the discussion is a mutual dialog of a subject involving winners and losers, argumentation is a social process in which individuals exchange ideas with each other by suggesting evidence. In the classes where argumentation is used, there are not students competing with each other, but students who learn together by exchanging ideas with the available data and the suggested evidence (Duschl \& Osborne, 2002).In this class students learn because of an environment of social interaction (Vygotsky, 1978).

Argumentation is at the center of creating scientific knowledge. Arguments about the suitability of experimental designs, interpretation of data, and validity of scientific claims are at the center of science because quality control in science is provided by the argumentation that scientists carry out in this process (Kuhn, 1992; Erduran et al., 2004).In short, it can be said that argumentation has an important role in the development and change of scientific knowledge. Therefore, argumentation has an important place in science education in terms of cognitive value (Kuhn, 1992). Learning and applying the rules of argumentation in science classes where students participate in small and large group discussions will also contribute to the training of science literate individuals, which is the main purpose of Turkish science curriculum (K3-8) like other countries (Berland \& Reisier, 2011; Erduran et al., 2004; Kaya \& Kılıç, 2008; Sampson \& Clark, 2011).Conceptual understanding develops when students support each other with qualified arguments or refute each other's arguments as part of such a process (Berland \& Reisier, 2011; Erduran et al., 2004; Zohar \& Nemet, 2002). In addition, comprehending the link between data and claim, understanding the relationship between claims and rationale, and strengthening students' ability to think critically in a scientific context prevents them from being blinded by obligations such as repetition and doing homework (Quinn, 1997, as cited in Erduran, et al., 2004).

\section{Argument and Types of Argumentation:}

Argument means evidence, proof, thesis, claim andaverment (Turkish Language Association [TDK], 2014). In a broader sense, it is a coordination of theories and evidence put forward to support or refute an opinion (Toulmin, 1958). It can be said that the argument is the ideas put forward during the argumentation process and the quality of the argumentation can be evaluated according to the type and quality of the argument used (Zohar \& Nemet, 2002).

In the literature, the argument is discussed in three categories as analytical, rhetorical and dialectical (van Eemeren et al., 1996). Analytical arguments are based on Aristo's logic theory. In the use of "analytical" arguments, the result is reached by reasoning based on deductive or inductive grounds. The following examples can be given to the analytical argument: current."

"All metals conduct electric current. Zinc is also a metal, so zinc also conducts electric

"Metals such as zinc, copper and iron transmit electric current. So all metals conduct electric current."

In the arguments given above, if the first proposition accepted by the person is correct, the other proposals and the result reached accordingly are true, and if the first proposition is false, the result will be false (Balcl, 2015). For example, a person starting out from the proposition that all the tastes of sour food are acidic may reach a false conclusion, thinking that a sweet apple is not acidic. In this context, it can be said that it is important to set out from truth-checked propositions. 
Rhetorical arguments are used to explain the subject to others and to persuade others to the accuracy of the subject (Driver et al., 2000). It emphasizes the need to convince the other by using more scientific knowledge (Duschl, Ellenbogen \& Erduran, 1999). Examples of such arguments are when a teacher presents statements about the subjectto a student or a doctor's statements about a treatment toa patient in a logical framework and persuasively. The rhetorical form of argumentation is usually monologic; it occurs when teachers develop evidence and create arguments for students (Driver, Newton and Osborne, 2000). The following statement can be given as an example to the rhetorical argument:

"Do not eat sugar on the feast, because all the candies contain corn syrup. Corn syrup, which affects our health quite badly, is 7 times more dangerous than white sugar and damagesour cells. At the same time, corn syrup, which lubricates the liver, is 7 times more toxic than white sugar."

The type of argumentation in which different views are tested and the purpose is to reach consensus on reasonable claims or actions is called dialectical argumentation. The dialectical argumentation process requires considering alternative ideas by creating a justification, and the debate reconstructs or changes personal ideas when it deems necessary (Driver et al., 2000). In order to reach alternative ideas in this argumentation process, existing thoughts need to be discussed and reasoned. While creating the dialectical argument, the subject is examined from different perspectives and proceeds with contradictions (Kuhn, 1992). Below is an example of a dialectical argumentation dialogue that can take place between students:

Student A:I think the rupture of the paper is a chemical change. Because the substance cannot be reinstated as a result of chemical changes. We cannot recover the torn paper as a whole paper.

Student B:I do not agree with you. Because I think the paper is the same, only the size has changed.

Student C:Yes, I also think only the size of the paper has changed, and the internal structure has not changed. Our teacher said that in order for a chemical change, the internal structure of the substance, that is, its identity, must change. But here the identity of the paper does not change. But I'm not sure about reversing it, guys.

Student A:Yes, I too remember what our teacher said. But in addition to this, our teacher said that chemical changes are irreversible, that the substance undergoing chemical change gained a new identity. I think the paper has undergone a chemical change since the torn paper cannot be recovered.

Student $D$ :Yes, you are right that the substance gains a new identity in chemical changes. For example, burning paper is a chemical change. When paper burns, it turns into ash. But I'm not sure about the rupture of the paper.

Student C:Yes, in our science textbook the other day, symptoms such as taste, smell, color change and gas output were observed in chemical changes. When the paper burns, smoke comes out, i.e. gas is released, and when the paper burns, it cannot be reversed. So I think the burning of the paper is chemical change. However, because the symptoms written in the book do not occur in the rupture of the paper, the rupture of the paper is a physical change.

Student A:Friends, you may be right, but if we examine the physical and chemical changes in terms of the reversibility of the event, which result will come out?

Student B:I think it would be hard for us to decide if we look at it from that point of view. If the internal structure of the substance is changing and there are symptoms such as gas 
release, we can say chemical, if the internal structure of the substance does not change, we can say physical change.

Student C:I think it makes more sense to look at it from this point of view. In addition, breaking the matter into small dimensions does not change the identity of the substance, it only physically changes its size. For example, slicing the bread, just like tearing the paper, is also a physical change, because the bread only changes in size, its taste, color, smell, etc. properties do not change.

Student A:So our teacher is right, chemical changes cannot be revesed because the identity of the substance, the internal structure, is changing. But there may also be physical changes that cannot be reversed. For example, the paper is the same as the paper is torn, but we cannot make the torn paper into a whole paper, do we?

Student B: Yes, my friend. It is not true to say that physical changes can definitely be recycled or not. Because both situations can happen. As you said, the rupture of the paper cannot be revesed, but the changes of state can be reversed. For example, if the evaporated water is cooled, it can be liquefied again.

Student A:Ok, now I got it better, thank you guys.

When the literature is examined, it is seen that the three types of arguments have some similarities and differences. A comparison of the properties of analytical, rhetorical and dialectical arguments is given in Table 1 (van Eemeren et al., 1996, p.33).

Table 1. Features of analytical, rhetoric and dialectical arguments

\begin{tabular}{cccc}
\hline $\begin{array}{c}\text { Type of } \\
\text { Argumentation }\end{array}$ & Analytical & Rhetorical & Dialectical \\
\hline $\begin{array}{c}\text { Objective } \\
\begin{array}{c}\text { Status of the } \\
\text { Premises }\end{array}\end{array}$ & Certainty & Persuasiveness & Acceptability \\
Inference & Validently true & Persuasive to audience & Acceptable \\
\hline
\end{tabular}

Since the analytical argument is mostly based on classical logic, it can be said that the use of rhetoric and dialectical arguments is more common in science classes today (Balcl, 2015). In this context, models of Toulmin, which is the representative of the rhetorical argumentation model, and Walton, which is the representative of the dialectical argumentation model, are given below.

\section{Toulmin and Walton Argumentation Models}

Stephen Toulmin (1958), in his book 'The Uses of Arguments', talked about the fact that people produce arguments in informal environments by breaking the norms of classical logic in argumentation and laid the foundations of rhetoric argumentation by examining the basic components that form an argument and the functional relationships between these components (Aktamış \& Hiğde, 2015).According to Toulmin, the argument consists of three basic factors such as data, claim and warrant, and three auxiliary elements as qualifier,rebuttal and backing(Toulmin, 1958). The diagram indicating the basic relationship between theseelements is shown in Figure-1. According to Toulmin (1958), the claim is views on the values and existences in people's minds. The data are expressions used as evidence to support the 
allegations put forward, and the warrant explains and establishes the relationship and coordination between the data and the claim. While the qualifier states the specific situations in which the claim put forward by the individual may be true, the backing is mostly assumptions that are not directly presented and addressed to reinforce the rationale. Rebuttal, on the other hand, is statements that state situations where claims cannot be accepted correctly.

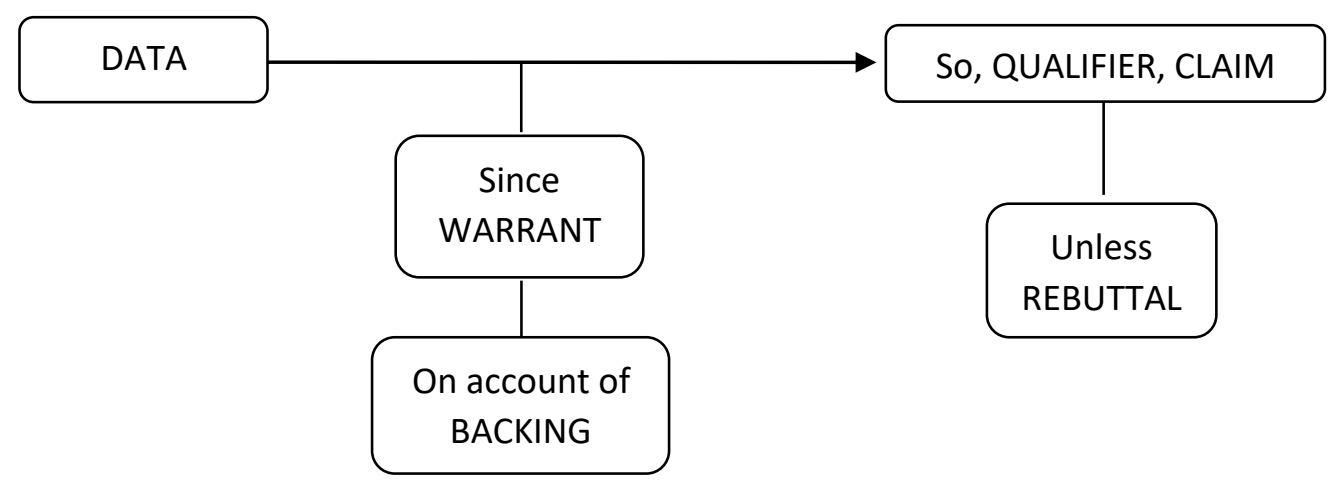

Figure 1. Schematic representation of the Toulmin argumentation model (Toulmin, 1958)

Toulmin's model is able to respond to today's needs better by bringing a proper critique to the sovereignty of formal logic for centuries. Toulmin model can also be used to improve argumentation skills of the participants in argument. However, serious criticism was also brought to the model. Knowing the limitations besides the benefits it offers (e.g., enabling analysis by slowing down the process, helping explicit assumptions to be made clear, enabling discussion to be perceived as an interactive process of reasoning, developing discussion skills, gaining critical point of view to the discussers, etc.) can help to use the model effectively in instructional practices (Aldağ, 2006). Although Toulmin's argumentation model may seem as a critical dialogue between the speaker and the listener in a dialectical contextat first glance, this approach is actually rhetorical and based more on monologue (van Eemeren \& Grootendorts, 2004).The rhetorical structure of scientific argumentation is monologic, has limitations in educational situations, and the listener's thought plays little role in argument formation (Boulter \& Gilbert, 1995). Although it is considered effective in the use of evidence and data in rhetorical discussions, Toulmin model is considered to be inadequate in the analysis of long, complex and especially dialectical discussions (Duschl et al., 1999; Driver et al., 2000). Also, since the model is not specific for any field, the argument elements in the model must be determined and analyzed for a certainfield (law, education, etc.). Moreover, Toulmin's different definitions of elements make it difficult to distinguish and evaluate these elements in argument analysis (Driver et al., 2000).

There are also alternative models to Toulmin model in the literature like Beardsley's (1950) convergent, divergent and serial discussion structures, Thomas's (1973) tree diagram, Scriven's (1976) seven-step approach, Walton's (1996) argumentation schemes and Lawson's (2003) hypothetical-deductive argument model. It can be said that Walton's works (Walton 1996; 1999) attracted more attention in terms of being dialectical from these models. Because Walton brought a different perspective to argumentation and brought forward the dialectical feature of argumentation (Kaya \& Kılıç, 2008).

Unlike Toulmin's model, which focuses on the elements of an argument (data, claim, warrant etc.), Walton's model is based on various arguments (Erduran \& Jiménez-Aleixandre, 2012). Walton made an important contribution to the field of argumentation with the concept of "new dialect". "New dialect" is about the arguments that are widely brought up in daily life. In Walton model, arguments are based on presumptive reasoning rather than deductive or inductive classical logic. Walton's dialectic has a lot in common with the old dialectic of Plato and Aristotle. As a difference, in Walton's new dialectic, discussions are analyzed and evaluated 
based on the purpose of the dialogue. When evaluating the plausibility and reasonableness of an argument, dialogue should be measured by its own standards (Walton, 1999). Analysis of arguments should be made within the framework of a general outline of a dialogue structure in which the actions of the participants, their position in the discussion, their commitments, and all other factors that define the dialogue change are clearly and fully defined (van Eemeren \& Grootendorst, 1999).

Presumptive reasoningleads to a conclusion by inference. The conclusion reached is temporary and is based on an estimate or assumption that it may change when new information is introduced. The argumentation schemes that focus on hypothetical reasoning determined by Walton focus on the evidence used by a person's argument and the starting point of the argument. This starting point can be a sign, expert opinion, evidence, cause, bias, analogy, knowledge, reason, etc. An argument, according to Walton, is rational as long as it is accepted. Walton sees argumentation as the exchange of dialogue between the parties discussing together, and argumentation schemes make it easier to identify and evaluate the arguments in everyday discourse (Walton, 1999).

Duschl (2007) compared students' argumentation skills using Toulmin argumentation model and Walton argumentation schemes. He concluded that the use of Walton's hypothetical reasoning processes rather than Toulmin argumentation model was more suitable for group dialectic and reasoning processes.It was also found that students developed more argumentation schemes in case of using dialectical argumentation. Researcheralso noted that Walton schemes canespecially be used to analyze the dialectical nature of small group discussions.

Although Toulmin argumentation model provides a basic structure despite its limitations (Venville \& Dawson, 2010), it is the most commonly used argumentation model in science education (Acar \& Patton, 2012; Berland \& Mc Neill, 2010; Berland \& Reiser, 2009; Clark \& Sampson, 2007; Dawson \& Venville, 2009; Erduran et al., 2004; Foong \& Daniel, 2013; Jimenez Aleixandre, Rodriguez \& Duschl, 2000; Kelly, Druker \& Chen, 1998; Kolstø, 2007; Osborne, Erduran \& Simon, 2004; Osborne et al., 2016; Sadler \& Donnely, 2006; Sadler \& Fowler, 2006; Ryu \& Sandoval, 2012; Venville \& Dawson, 2010; Yang, Lin, She \& Huang, 2015; Yerrick, 2000). The number of researchers working dialectical argumentation compared to Toulmin model is less, while Walton schemes are used in some of these studies (Duschl, 2007; Özdem Yllmaz, 2014; Özdem, Ertepinar, Çakiroglu \& Erduran, 2013). Walton schemes were not used in many of this dialectical studiesand the dialectical nature of argumentation was tried to be solved by researchers (Albe, 2008; Chin \& Teou, 2009; Dung, Kowalski \& Toni, 2006; Feteris, 2006; Grasso, Cawsey \& Jones. 2000; Kim \& Song, 2005; Naylor, Keogh \& Downing, 2007; Nielsen, 2012; Nussbaumm, Sinatra \& Poliquin, 2008; Yun \& Kim, 2015).

\section{The Aim and Reason of the Research}

Since argumentation is intertwined with the learning outcomes in science education programs, it has been frequently preferred to adapt it to science education studies, so the number of argumentation studies in science education has increased.In this context, in order to reveal what kind of improvements the argumentation has made in science education during the past several decades, methodology of argumentation studies the researchers chose, how they applied these methods and what conclusions they reached regarding the application of these methods may be important to see the overall effect of the use of the method.For this purpose, there are some studies conducted in the literature. For example, Erduran, Özdem and Park (2015) examined studies published in three journals covering 1998-2014 (Science Education, International Journal of Science Education and Journal of Research in Science Teaching) in order to determine the effectiveness of argumentation studies and trends in this field.The articles discussed in this study were analyzed in terms of the publication year, the cognitive (finding evidence, explaining, reasoning) and linguistic (negotiation, speaking, discussion, etc.) aspects of argumentation and the distribution of these keywords by years. Bağ and Çalık (2017), on the other hand, conducted a thematic content analysis of argumentation studies only at primary and middle schools 
between 2006-2016. However, in order to determine the trends in the field more clearly, the studies carried out in all teaching levels in the literature should be examined more deeply. In this regard, the categories mentioned above differ from the themes discussed in these studies to determine the trends of argumentation studies.Especially in this study, the application processes of argumentation the researchers chose were examined in depth and compared in terms of the dialectical processes experienced by the students in rhetoric and dialectical argumentation. Because the dialectical processes that students experience when they are forced by their peers in the process of argumentation can help them obtain more detailed information in the field they are discussing, change or revise world views and develop more appropriate forms of reasoning (Orsolini \& Pontecorvo 1992; Pontecorvo \& Girardet 1993; Pontecorvo \& Pirchio 2000). When the literature is examined, there is no thematic content analysis study comparing rhetorical and dialectical argumentation. Based on this lack of literature, it was aimed to compare the rhetoric argumentation studies and dialectical argumentation studies in which Toulmin model was used directly or rearranged in terms of objectives, sampling feature, subject area, data collection and analysis method, application process and results of argumentation.

\section{METHODOLOGY}

In this study, content analysis method was used for the purpose. Content analysis is carried out to determine the existence, meanings and relationships of certain words and concepts in a set of text or texts (Büyüköztürk, Kılıç Çakmak, Akgün, Karadeniz \& Demirel, 2016, p. 250). Content analysis has a wide application in educational research (Fraenkel \& Wallen, 2000). Content analysis provides a clearer view and evaluation of the study results (Henson, $1997 ; 1999 ; 2001)$. In addition, it makes a great contribution to the related literature in terms of the quality and usefulness of the studies (Tsai\& Wen, 2005).

\section{Data Collection}

Firstly, it was decided to examine four academic journals in the field of science education within the scope of the research. These journals are "Journal of Research in Science Teaching, Science Education, International Journal of Science Education and Research in Science Education", which are indexed in the Social Sciences Citation Index (SSCI), which is thought to be highly compatible with international standards and index thousands of qualified journals. These journals are also indexed in the Education Resources Information Center (ERIC) and GOOGLE SCHOLAR directory. Various keywords such as "argumentation", "argumentation in science education", "argumentation in science", "argumentation in physic / chemistry / biology" have been used to reach the argumentation studies conducted in related journals. As a result of the search, 81 articles in these four journals related to argumentation in science education were taken into preliminary examination. In the preliminary examination conducted jointly by the two researchers, the articles were re-examined and a total of 34 articles suitable for the study were evaluated.In order to ensure a selective-critical elimination while determining the articles, it was used as a criterion whether the argumentation was applied in classroom or online environment.So,only experimental and case studies were analyzedin the study.In addition, studies of the same authors on similar topics were not included in the current study, and attention was paid to have at most three studies of the same author in order to ensure diversity. For example, there are eight articles by Jonathan Osborne published in the determinedjournals. In these articles, only three of them were included in the study because the author and / or his team worked on similar argumentation processes, that is, the ways they applied the argumentation were the same. The articles evaluated in the scope of the research are indicated with $(*)$ in the bibliography.

\section{Data Analysis}

The research was carried out by following the content analysis steps. Coding criteria were established by determining the main themes to be sought in the articles by the researchers. As a result of the consensus reached by the researchers, the aim of the research, the sample of the 
research, the subject of the research, the data collection and analysis method used in the research, the argumentation process and the results of the research were determined as the main themes and the codes were created within the framework of these main themes. While coding the data about the results of the studies, only the results obtained about the argumentation model were considered.Because, in this study, it was considered how the argumentation process should be carried out rather than the impact of argumentationon the student learning outcomes (see Table 3). For this reason, results related to the relation of argumentation method with dependent variables such as students' academic success, attitude, and critical thinking skills are not included in coding.

In accordance with the purpose of the study, the compatibility between independent observers was examined as a criterion of reliability. In order to ensure consistency between coders, 5 articles randomly selected from the articles were examined together according to the main and sub-themes determined by the two researchers,and a consensus was reached. Then, 5 more articles were randomly selected so thatthe researchers examine these articles independently.Results were compared, and the compatibility and incompatibilities between the codes were determined. Miles and Huberman (1994, p.64) refer to the codes that are similar to each other as the "Consensus" and the codes that are not as "Disagreement" and for coder reliability, suggest the formula of:

$$
\text { Reliability }=\text { Consensus } / \text { (Consensus }+ \text { Disagreement }) * 100
$$

When two researchers examined 5 articles independently, comparing the codings, it was observed that there was a consensus in 132 codes out of a total of 145 codes, while disagreement was observed in 13 codes. By using these values, the compatibility between the observers with the above-mentioned formula was found to be $91 \%$.It was seen that the compatibility between the observers was sufficient. Then, the researchers examined the remaining articles individually, and the disagreements identified were resolved by discussing and finalizing the coding.

\section{FINDINGS}

$26(76 \%)$ of the 34 articles examined in the study are examples of rhetorical argumentation(Berland \& Mc Neill, 2010; Berland \& Reiser, 2009; Chang \& Chui, 2008; Clark \& Sampson, 2007; Dawson \& Venville, 2009; Erduran et al., 2004; Foong \& Daniel, 2013; Jimenez Aleixandre et al., 2000 ; Grimes, McDonald \& van Kampen, 2019; Kelly, Druker \& Chen, 1998; Kolstø, 2007; Kutluca \& Aydın, 2017; Liu, Liu \& Lin, 2019; Mc Neill, 2011; Moon, Stanford, Cole \& Towns, 2017 ; Osborne et al., 2004; Osborne et al., 2016; Pabuçcu \& Erduran, 2017; Ryu \& Sandoval, 2012; Sadler \& Donnely, 2006; Sadler \& Fowler, 2006; Venville \& Dawson, 2010; Yang \& Lin, 2015; Yerrick, 2000; Weng, Lin \& She, 2017; Zhu, Lee, Wang, Liu, Belur \& Pallant, 2017),and 8 (24\%) are examples of dialectical argumentation(Albe, 2008; Chin \& Teou, 2009; Gonzalaes-Howard \& McNeill, 2017; Kim \& Song, 2005; Naylor, Keogh \& Downing, 2007; Nielsen, 2012; Nussbaum, Sinatra \& Poliquin, 2008; Yun and Kim, 2015 ).

When Table 2 is analyzed, it is seen that four different codes were created related to the "aim" theme. In most of the studies (35\%), it was aimed to determine the effect of various effects such as online argumentation, the effect of students' preliminary information on the argumentation process (Chin \& Teou, 2009; Liu, Liu \& Lin, 2019 etc.). In some of the studies (29\%), it was carried out for making an assessment about the argumentation situation (Jimenez Aleixandre et al., 2000; Mc Neill, 2011 etc.) in order to determine students' argumentation skills; in some (24\%), it is aimed to examine the argumentation process (Kim \& Song, 2005; Pabuçcu \& Erduran, 2017 etc.). In a limited number of studies (12\%), was carried out for determining the effect of argumentation on various variables such as success and attitude (Kutluca \& Aydın, 2017; Nussbaum et al., 2008 etc.).

When Table 2 is examined, it is seen that six different codes were created regarding the theme of "sample", namely "number of participants, primary school, secondary school, high 
school, university and teacher". Results for Sample size code showed that the sample sizewas generally limited in the argumentation studies ( $<100$ ) (Kelly et al., 1998; Naylorvd., 2007 etc.). Research carried out by Osborne et al. (2016) is the study with the largest number of participants among the studies examined with a sample group of 803 . While $3(9 \%)$ of the reviewedstudies were related to primary school(Berland \& Mc Neill, 2010; Naylor et al., 2007 etc.), 14 (41\%) of them were secondary school(Chin \& Teou, 2009; Yang \& Lin, 2015 etc.), 13 (38\%) were high school(Albe, 2008; Osborne et al., 2016, etc.), $6(18 \%)$ were related to the argumentation of students at university level(Chang \& Chui, 2008; Nussbaum et al., 2008 etc.), and $3(9 \%)$ research was related to science teachers (Kim \& Song, 2005; Osborne, et al., 2004 etc.).

There are 4 different codes related to the subject area theme, namely physics, chemistry, biology and socioscientific issues(Table 2). While $22(65 \%)$ of the articles are related to scientific (physics, chemistry, biology) subjects (Mc Neill, 2011; Yun and Kim, 2015 etc.) 10 (29\%) of them are related to socioscientific issues(Nielsen, 2012; Venville \& Dawson, 2010 etc.), $2(6 \%)$ of them are related to both scientific and socioscientificissues (Erduran et al., 2004; Osborne et al., 2004).In addition, as a data analysis method, qualitative method in 16 (47\%) articles (Albe, 2008; Berland \& Reiser, 2009 etc.), mixed method in 16 (47\%) (Nussbaum et al., 2008; Yang \& Lin, 2015 etc.) and quantitative method in 2 (6\%) of the studies (Weng et al., 2017; Zhu et al., 2017)wereused.

As a result of the findings, three different codes were created for the argumentation process: adding new elements to the process, using argumentative indicators in the process and developing rubrics for argumentation analysis. In most of the studies (65\%), various rubrics have been developed to evaluate the argumentation process (Yerrick, 2000; Chin \& Teou, 2009, etc.) In some studies (15\%) words such as "because" and "so" are used as argumentative indicators (Erduran et al., 2004; Chin \& Teou, 2009 etc.). In addition, in some rhetorical studies (26\%), new elements such as evidence, reasoning, and challenge have been added to adapt the argumentation models to science education (Clark \& Sampson, 2007; Ryu \& Sandoval, 2012 etc.).

When Table 2 is analyzed, the codes obtained in terms of the results of the reviewed studiesare: it is difficult to distinguish the basic elements of Toulmin model (Kelly et al., 1998; Sadler \& Fowler, 2006 etc.), Toulmin model reduces the dialectical properties of argumentation, (Albe, 2008; Nielsen, 2012) that students should have sufficient scientific knowledge to be successful in the argumentation process (Kolstø, 2007; Liu, Liu \& Lin, 2019 etc.), students use the evidence to support their claims (Moon et al., 2017; Naylor et al., 2007 etc.), and teacher's guidance (feedback, prompt, etc.) during the argumentation process increased the quality of the argumentation (Nussbaum et al., 2008; Weng et al., 2017 etc.).There are also conclusions that the use of scientific information as evidence in the argumentation of socioscientificissues can make evaluation of argumentation difficult (Nielsen, 2012), the argumentation process should not be monologic (Kutluca \&. Aydın, 2017; Nielsen, 2012), the information provided to students in the argumentation process is sometimes not used correctly by students (Pabuçcu \& Erduran, 2017), and Toulmin model is insufficient to analyze the argumentation process and new elements should be added to the model (Grimes et al., 2019).

In some of the studies examined, more than one method, data collection tool or data analysis method was used. In these studies, since a theme contains more than one code, the same theme has been coded more than once. This situation caused the frequency values of the codes of the theme examined to exceed the total number of studies. For example, a total of 39 codes related to the feature of samplewere created (primary school-3, middle school-14, high school-13, university-6, teacher-3), because some studies have been carried out withmore than one sample group.The frequency and percentage values of the articles included in the content analysis in terms of aim, sample, subject area, data collection and analysis method, argumentation process and obtainedresults are presented in Table 2 and Table 3. Details of the findings regarding the studies examined are given in Appendix1 and Appendix2. 
Table 2.Comparison of rhetorical and dialectical studies in terms of aim, sample, subject area and data collection and analysis method

\begin{tabular}{|c|c|c|c|c|c|c|c|c|c|c|c|c|c|c|c|c|c|}
\hline Themes & \multicolumn{4}{|c|}{ Aim of research } & \multicolumn{6}{|c|}{ Features of samples } & \multicolumn{4}{|c|}{ Subject of reseach } & \multicolumn{3}{|c|}{ Method } \\
\hline$\frac{\mathscr{d}}{0}$ & 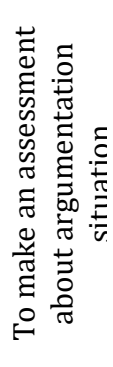 & 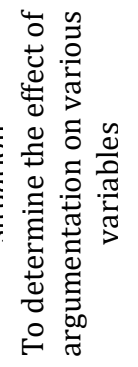 & 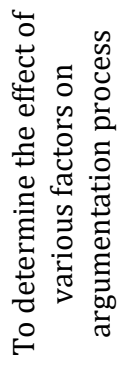 & 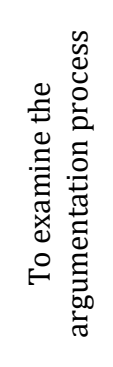 & 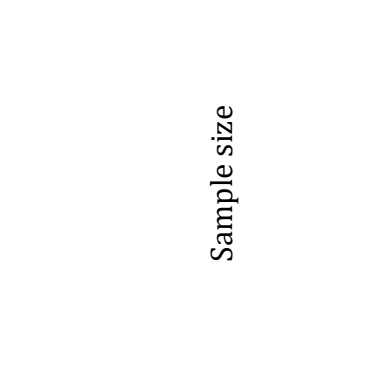 & 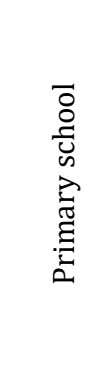 & 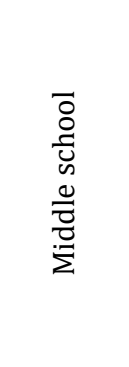 & 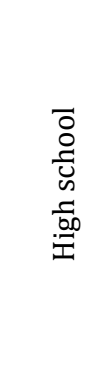 & 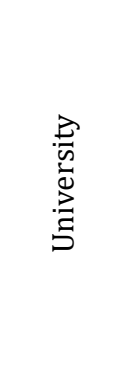 & 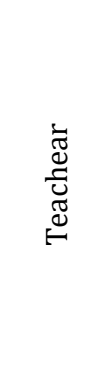 & 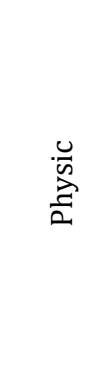 & 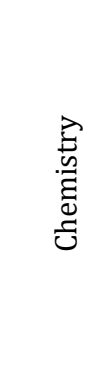 & $\begin{array}{l}\overrightarrow{00} \\
\stackrel{0}{\circ} \\
.0\end{array}$ & 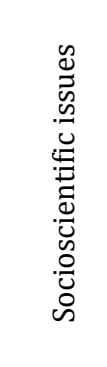 & 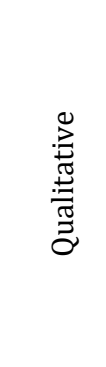 & 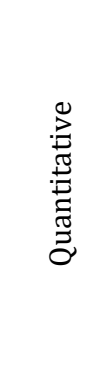 & $\begin{array}{l}\vec{\Downarrow} \\
\stackrel{x}{\Sigma}\end{array}$ \\
\hline 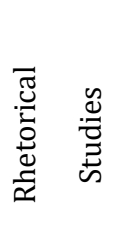 & $\begin{array}{c}9 \\
(\% 26)\end{array}$ & $\begin{array}{c}3 \\
(\% 9)\end{array}$ & $\begin{array}{c}10 \\
(\% 29)\end{array}$ & $\begin{array}{c}4 \\
(\% 12)\end{array}$ & $\begin{array}{l}\text { Between 0-50:2(\%35) } \\
\text { Between 51-100:6(\%18) } \\
\text { Between 101-150:3(\%9) } \\
\text { Between 151-200:1(\%3) } \\
201 \text { and above: } 3(\% 9) \\
\text { Not clear (NC):1(\%3) }\end{array}$ & $\begin{array}{c}2 \\
(\% 6)\end{array}$ & $\begin{array}{c}10 \\
(\% 29)\end{array}$ & $\begin{array}{c}11 \\
(\% 32)\end{array}$ & $\begin{array}{c}5 \\
(\% 15)\end{array}$ & $\begin{array}{c}2 \\
(\% 6)\end{array}$ & $\begin{array}{c}9 \\
(\% 26)\end{array}$ & $\begin{array}{c}4 \\
(\% 12)\end{array}$ & $\begin{array}{c}9 \\
(\% 26)\end{array}$ & $\begin{array}{c}10 \\
(\% 29)\end{array}$ & $\begin{array}{c}11 \\
(\% 32)\end{array}$ & $\begin{array}{c}2 \\
(\% 6)\end{array}$ & $\begin{array}{c}13 \\
(\% 38)\end{array}$ \\
\hline 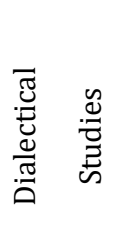 & $\begin{array}{c}1 \\
(\% 3)\end{array}$ & $\begin{array}{c}1 \\
(\% 3)\end{array}$ & $\begin{array}{c}2 \\
(\% 6)\end{array}$ & $\begin{array}{c}4 \\
(\% 12)\end{array}$ & $\begin{array}{l}\text { Between 0-50:3(\%9) } \\
\text { Between 51-100: 3(\%9) } \\
\text { Between 101-150:- } \\
\text { Between 151-200:- } \\
201 \text { and above:- } \\
\text { Not clear (NC):2(\%6) }\end{array}$ & $\begin{array}{c}1 \\
(\% 3)\end{array}$ & $\begin{array}{c}4 \\
(\% 12)\end{array}$ & $\begin{array}{c}2 \\
(\% 6)\end{array}$ & $\begin{array}{c}1 \\
(\% 3)\end{array}$ & $\begin{array}{c}1 \\
(\% 3)\end{array}$ & $\begin{array}{c}4 \\
(\% 12)\end{array}$ & $\begin{array}{c}0 \\
(\% 0)\end{array}$ & $\begin{array}{c}3 \\
(\% 9)\end{array}$ & $\begin{array}{c}2 \\
(\% 6)\end{array}$ & $\begin{array}{c}5 \\
(\% 15)\end{array}$ & $\begin{array}{c}0 \\
(\% 0)\end{array}$ & $\begin{array}{c}3 \\
(\% 9)\end{array}$ \\
\hline 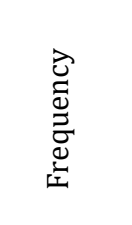 & $\begin{array}{c}10 \\
(\% 29)\end{array}$ & $\begin{array}{c}4 \\
(\% 12)\end{array}$ & $\begin{array}{c}12 \\
(\% 35)\end{array}$ & $\begin{array}{c}8 \\
(\% 24)\end{array}$ & 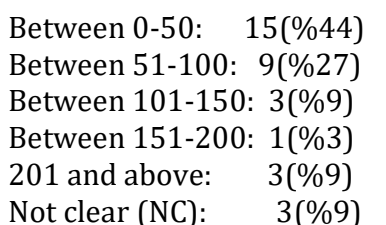 & $\begin{array}{c}3 \\
(\% 9)\end{array}$ & $\begin{array}{c}14 \\
(\% 41)\end{array}$ & $\begin{array}{c}13 \\
(\% 38)\end{array}$ & $\begin{array}{c}6 \\
(\% 18)\end{array}$ & $\begin{array}{c}3 \\
(\% 9)\end{array}$ & $\begin{array}{c}13 \\
(\% 38)\end{array}$ & $\begin{array}{c}4 \\
(\% 12)\end{array}$ & $\begin{array}{c}12 \\
(\% 35)\end{array}$ & $\begin{array}{c}12 \\
(\% 35)\end{array}$ & $\begin{array}{c}16 \\
(\% 47)\end{array}$ & $\begin{array}{c}2 \\
(\% 6)\end{array}$ & $\begin{array}{c}16 \\
(\% 47)\end{array}$ \\
\hline
\end{tabular}

Table 3. Comparison of rhetorical and dialectical studies in terms of argumentation process and results

62| KAHRAMAN \& KAYA A thematic content analysis of rhetorical and dialectical argumentation studies in science education 


\begin{tabular}{|c|c|c|c|c|c|c|c|c|c|c|c|c|}
\hline Themes & \multicolumn{3}{|c|}{ Argumentation process } & \multicolumn{9}{|c|}{ Results } \\
\hline$\frac{\tilde{d}}{0}$ & 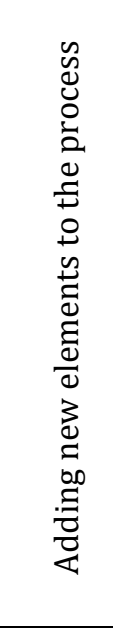 & 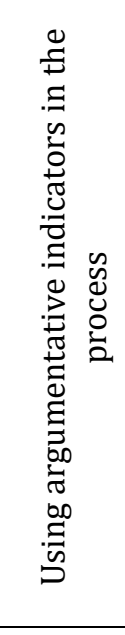 & 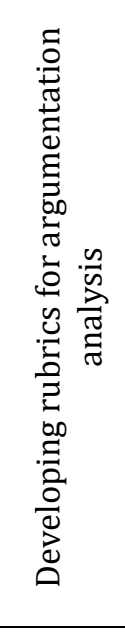 & 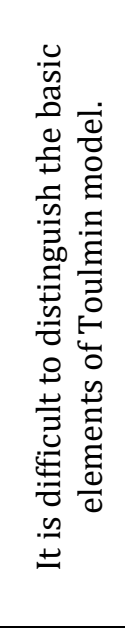 & 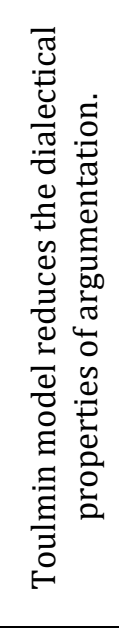 & 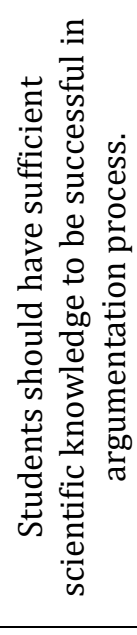 & 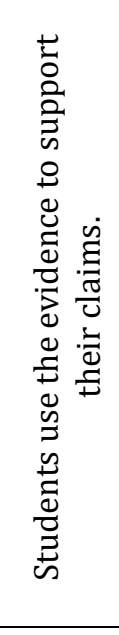 & 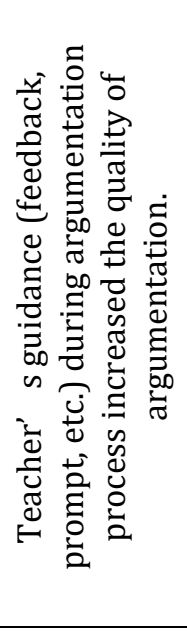 & 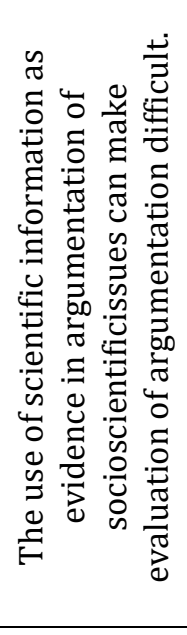 & 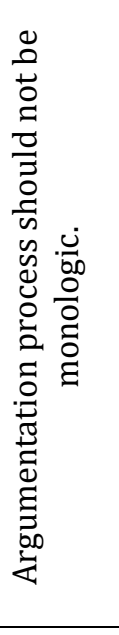 & 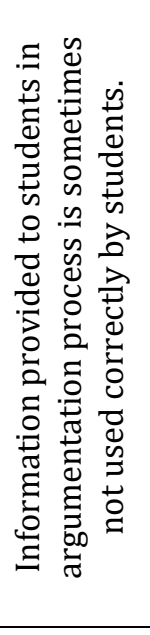 & 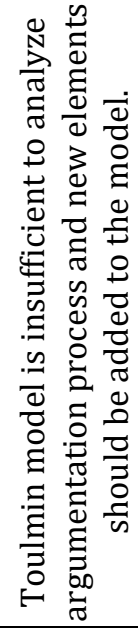 \\
\hline 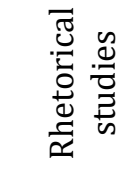 & $\begin{array}{c}9 \\
(\% 26)\end{array}$ & $\begin{array}{c}4 \\
(\% 12)\end{array}$ & $\begin{array}{c}17 \\
(\% 50)\end{array}$ & $\begin{array}{c}5 \\
(\% 15)\end{array}$ & - & $\begin{array}{c}13 \\
(\% 38)\end{array}$ & $\begin{array}{c}11 \\
(\% 32)\end{array}$ & $\begin{array}{c}7 \\
(\% 20)\end{array}$ & - & $\begin{array}{c}1 \\
(\% 3)\end{array}$ & $\begin{array}{c}1 \\
(\% 3)\end{array}$ & $\begin{array}{c}1 \\
(\% 3)\end{array}$ \\
\hline 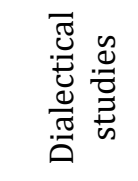 & - & $\begin{array}{c}1 \\
(\% 3)\end{array}$ & $\begin{array}{c}5 \\
(\% 15)\end{array}$ & $\begin{array}{c}5 \\
(\% 15)\end{array}$ & $\begin{array}{c}2 \\
(\% 6)\end{array}$ & - & $\begin{array}{c}2 \\
(\% 6)\end{array}$ & $\begin{array}{c}3 \\
(\% 9)\end{array}$ & $\begin{array}{c}1 \\
(\% 3)\end{array}$ & $\begin{array}{c}1 \\
(\% 3)\end{array}$ & - & - \\
\hline 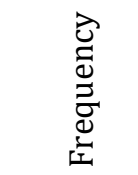 & $\begin{array}{c}9 \\
(\% 26)\end{array}$ & $\begin{array}{c}5 \\
(\% 15)\end{array}$ & $\begin{array}{c}22 \\
(\% 65)\end{array}$ & $\begin{array}{c}10 \\
(\% 29)\end{array}$ & $\begin{array}{c}2 \\
(\% 6)\end{array}$ & $\begin{array}{c}13 \\
(\% 38)\end{array}$ & $\begin{array}{c}13 \\
(\% 38)\end{array}$ & $\begin{array}{c}10 \\
(\% 29)\end{array}$ & $\begin{array}{c}1 \\
(\% 3)\end{array}$ & $\begin{array}{c}2 \\
(\% 6)\end{array}$ & $\begin{array}{c}1 \\
(\% 3)\end{array}$ & $\begin{array}{c}1 \\
(\% 3)\end{array}$ \\
\hline
\end{tabular}




\section{DISCUSSION, CONCLUSION AND SUGGESTIONS}

In this research, 34 articles published in leading journals of science education were examined. In most of the articles examined ( $\mathrm{n}=26,74 \%)$, the argumentation process was organized according to Toulmin argumentation model using rhetorical argumentation. As a result of the literature review, all dialectical studies that can be accessed in the determined science education journals wereanalyzed. Since there were large number of rhetorical studies, the studies conducted through similar methodology or procedure were not included in the analyzing process, as well as,maximum 3 studies of the same researcher were analysed. It can be said that the reason for using Toulmin model more in the literature is that rhetoric argumentation is more systematic and has certain rules. Similarly, Venville and Dawson (2010) stated that despite the limitations of Toulmin model, they used this model because it provides a profound structure.

When Tables 2 and 3 are examined, it can be seen that the publication years of the articles using Toulmin's rhetoric (1998-2019) are earlier than the publication years of the articles using dialectical argumentation (2005-2017). This situation may have resulted from the need to search for other models after criticisms of Toulmin model (Duschl et al., 1999; Driver et al., 2000; van Eemeren \& Grootendorts, 2004). Indeed, some researchers working on dialectical argumentation (Albe, 2008; Duschl, 2007; Nielsen, 2012) stated that Toulmin model was insufficient to analyze the dialectical properties of argumentation and stated that they did not prefer this model and studied on dialectical argumentation.

When the studies are analyzed in terms of their aims, it was seen in many articles that the general aim was to analyze student argumentation and to improve students' argumentation skills. Researchers developed various rubrics for this purpose and used different methods to make the argumentation process more effective. Thanks to the developed rubrics, the argumentation skill can be developed by analyzing student argumentation and thus revealing the student's level and deficiencies. Improving students' argumentation skills can merit the training of science literate individuals (Kaya \& Kılıç, 2008) by increasing their understanding of nature of science (Duschl \& Osborne, 2002).

Considering the results reached under the sample category related to the articles, it is seen that Sample size is under 100 people in many articles, and these participants are from different educational levels. Based on this result, it can be said that the researchers chose the appropriate sampling method while conducting their studies. Because, according to Büyüköztürk et al. (2016), proper sampling is done with the most accessible groups in order to prevent losses such as time, money and labor. However, using proper sampling is often not recommended. While Comrey and Lee (1992) described the sample size as $100=$ weak, $200=$ medium, $300=$ good, $500=$ very good and $1000=$ perfect, Aleamoni (1976) stated that Sample size should be at least 400 (as cited in Gül \& Sözbilir, 2015).

When analyzed in terms of subject area category, it was seen that most of the studies used argumentation on scientific subjects in physics, chemistry and biology. On the other hand, argumentation studies on socioscientific issues are fewer. However, although socioscientific issuesare controversial issues open to new arguments that do not have a definite consensus (Dawson \& Venville, 2009), the number of studies on the argumentation of these issues is not enough. Looking at the results of the research, most researchers using Toulmin model concluded that students should have sufficient scientific knowledge to be more successful in the argumentation process (Berland \& McNeill, 2010; Berland \& Reiser, 2009; Chang \& Chiu, 2008; Clark \& Sampson, 2007; Dawson \& Venville, 2009; Jimenez et al., 2000; Kolstø, 2007; Liu, Liu \& Lin, 2019; McNeill, 2011; Osborne et al., 2000; Sadler \& Donnely, 2006; Sadler \& Fowler, 2006; Yang \& Lin, 2015 ).Nielsen (2012) stated that using scientific information as evidence in dialectical argumentation of socioscientific issuescan make argument analysis difficult. This difficulty may be the reason why researchers have not done much research on the argumentation of socioscientific issues. On this topic, Nielsen (2012) pointed out that further 
studies are needed on how to use scientific knowledge in socioscientific discussions and especially how such activities can be evaluated by teachers.

It is seen that in most of the studies in which both rhetorical and dialectical argumentation models are used, data collection and analysis are performed by qualitative(studies using data collection and analysis methods such as sound recording, video recording, content analysis etc.) or mixed(where various tests and interviews are used together and analyzed together) research methods.These findings are not compatible with those of Wassink and Sadi (2016) and Tsai and Wen (2005) as they have stated that quantitative research is used more in science education research. Bağ and Çalık (2017) have linked the reason why more qualitative research is preferred for the analysis of argumentation because argumentation is a natural and intellectual discourse conducted using a language. Because, qualitative research is defined as the most appropriate method for argumentation analysis since it is defined as "the researcher's examination of naturally occurring phenomena in all its complexity" (Fraenkel \& Wallen, 2000, p.669).

As a result of the examinations, it was seen that researchers using Toulmin argumentation model accepted the limitations of this model and revised the model to show the dialectical processes they experienced (Berland \& Mc Neill, 2010; Berland \& Reiser, 2009; Clark \&Sampson, 2007; Grimes, McDonald \& van Kampen, 2019; Jimenez Aleixandre et al., 2000; Kelly et al., 1998; Mc Neill, 2011; Ryu \& Sandoval, 2012). These additions may result from Toulmin model not being developed for a particular field. As a matter of fact, according to Driver, Newton and Osborne, (2000), new elements should be added to the field in which Toulmin is used. In addition, some studies have attempted to distinguish data, claim, warrant, backing, qualifier and rebuttal elements by using argumentative indicators such as "because, but, I disagree..." to facilitate the determination of argumentation elements (Erduran et al., 2004; Mercer, Wegerif \& Dawes, 1999; Osborne et al., 2004; Yerrick, 2000).

The use of argumentative indicators in determining argument elements can also be part of these interpretations, parallel to the interpretation of the dialectical properties of the argument. In addition, these linguistic indicators can be a key point in the analysis of argumentation. (van Eemeren, Houtlosser \& Snoeck Henkemans, 2007). For example, the word "but" can sometimes be used as a counter argument against someone else's opinion, and sometimes it can be used by the speaker to distinguish various ideas in his own speech (Nielsen, 2013).A set of standard indicator words such as "But", "because", "so", "I don't think so", "why not?" does not always indicate that an argument is made; but can explain the action that is basically a discourse different from an argument (Govier 2010; as cited in Nielsen, 2013).This decomposition is a matter of interpreting the dialectic of the change at hand (Nielsen, 2013). Argumentative indicators are not just words used to describe the dialectical movements that the parties should do. It is also the best resource for identifying ways of strategic maneuver of discussions that discussers can use to steer the critical solution process to their side (van Eemeren, Houtlosser \& Snoeck Henkemans, 2007). Chin and Teou (2009) used indicator words to analyze students' dialectical arguments.According to the researchers, while words like "I think", "can", "maybe", "if" indicate the hypothetical nature of students' claims and reasoning, words like "therefore", "hence" and "even if" indicate reasons and expressions like "if so, it would be" refer to hypothetical deductive arguments.These argumentative indicators that the researchers put forward to determine the arguments of Toulmin argumentation model may point out that the elements of Toulmin model are difficult to distinguish from within speech and from each other. Indeed, researchers (Erduran et al., 2004; Osborne et al., 2004; Yerrick, 2000) stated that elements of the model are difficult to distinguish. It can be said that the difficulty of distinguishing elements of Toulmin rhetoric makes it difficult to determine the quality of argumentation. For this reason, a format is needed to evaluate the argumentation and various rubrics have been developed or previously developed rubrics have been used for argumentation analysis by researchers (Clark \&Sampson, 2007; Foong \& Daniel, 2013; Dawson \& Venville, 2009; Erduran \& Pabuçcu, 2017; Erduran et al., 2004; Liu, Liu \& Lin, 2019; McNeill, 2011; Moon, Stanford, Cole \& Towns 2017; Osborne et al., 2004; Osborne et al., 2016; Sadler and Donnely, 
2006; Sadler \& Fowler, 2006 ; Ryu \& Sandoval, 2012; Venville and Dawson, 2010; Weng, Lin \& She, 2017; Yerrick, 2000).

When the literature was examined, it was seen that evaluation forms were developed not only for rhetorical argumentation but also for the analysis of dialectical argumentation (Chin \& Teou, 2009; Gonzales-Howard \& McNeill, 2017; Naylor, Keogh \& Downing, 2007; Nussbaum, Sinatra \& Poliquin, 2008; Yun \& Kim, 2015). The development of rubrics and the use of argumentative indicators for the analysis of dialectical argumentation may also indicate that dialectic argumentation is difficult to analyze. When the developed rubrics are examined, it can be said that the rhetoric rubrics are mostly rated according to presence of the elements ofToulmin model's argument, and the dialectic rubrics are used to analyze the dialectical moves (such as the argument is open to various opinions, respond to other ideas in the group) and the source of the arguments.

When the results of the studies in terms of rhetorical and dialectical argumentation were examined, it was concluded that the students used the evidence to support their claims. Puvirajah (2007) emphasized that supporting arguments by providing evidence is the basis of creating a quality argument. As a matter of fact, the researchers pointed out the importance of using evidence in the argumentation process by adding the evidence element among the elements of Toulmin model and using it in the argumentation process (Berland \& Mc Neill, 2010; Berland \& Reiser, 2009; Mc Neill, 2011; Ryu \& Sandoval, 2012). According to Walton, the starting point of the argument may be evidence, and the evidenceenables students to make some inferences (Walton, 1999). In this context, it can be said that the use of evidence in both rhetorical and dialectical argumentation will increase the quality of argumentation.

Another result obtained from the content analysis is that the quality of the argumentation will increase by guiding students in both rhetorical and dialectical argumentation processes by the teacher (Chin \& Teou, 2009; Nussbaumm et al., 2008; Ryu \& Sandoval, 2012; Yang et al., 2015). According to the researchers, the application of some basic criteria and teacher guidance in the argumentation process can help students who do not participate in the argumentation to establish arguments and access scientific information. On the contrary, Naylor, Keogh and Downing (2007) argue that when students work in small groups in the absence of teachers, they can establish their own rules to manage the discussion by gaining equality. Moreover, Erduran and Pabuçcu (2017) stated that the information presented to the students by the teacher during the argumentation process is not guaranteed to be used correctly by the students. It can be said that more research should be done to reach a clearer conclusion in this regard.

Based on the above-mentioned results, the following suggestions can be made:

- Argumentation studies can be carried out by including larger sample groups and spread over a longer period of time.

- Since dialectical research is scarce, this practice is not fully understood. For a better understanding of this method, more dialectical argumentation studies can be done.

- The studies comparingToulmin rhetoric and dialectical studies are limited (Duschl, 2007; Özdem et al., 2013; Özdem Yllmaz, 2014). Increasing the number of these studies may shed light on future argumentation studies.

- It is unclear whether both rhetorical and dialectical argumentation methods are suitable for socioscientific issues. Increase of argumentation studies in socioscientific issues and the meta-analysis of results of these studies can help to understand its applicabilityof argumentation in socioscientific issues.

- The role of the teacher in the argumentation process is not fully specified in the results of the studies (whether the teacher will set rules, intervene in the argumentation process, etc.). To better determine this role, there is a need for argumentation studies in which the focusis on teachers.

- When looking at the implementation processes of argumentation, studies on online argumentation are limited (Clark \& Sampson, 2007; Nussbaumm et al., 2008; Yang et al., 2015; Zhu, Lee, Wang, Liu, Belur \& Pallant, 2017). By considering the importance of technology in science education, argumentation studies carried out in online environments 
can be increased and which argumentation model will be more suitable for online argumentation can be determined.

- This research is limited to only argumentation studies in the field of science education and four journals determined. For more in-depth information, argumentation studies in different fields and different publications and theses on argumentation can be examined.

\section{REFERENCES}

Acar, Ö. \& Patton, B. R. (2012). Argumentation and formal reasoning skillsin an argumentationbased guided inquiry course. Procedia - Social and Behavioral Sciences, 46, 4756 - 4760.

Aktamıș, H. \& Hiğde, E. (2015). Fen Eğitiminde Kullanılan Argümantasyon Modellerinin Değerlendirilmesi. Mehmet Akif Ersoy Üniversitesi Eğitim Fakültesi Dergisi, 35, 136 -172.

*Albe, V. (2008). When scientific knowledge, daily life experience, epistemological and social considerations intersect: Students' argumentation in group discussions on a socioscientific issue. Research in Science Education, 38, 67-90.

Aldağ, H. (2006). Toulmin tartışma modeli. C..̈̈. Sosyal Bilimler Enstitüsü Dergisi, 15(1), 13- 34.

Bağ, H. \& Çalık, M. (2017). İlköğretim Düzeyinde Yapılan Argümantasyon Çalışmlarına Yönelik Tematik İçerik Analizi . Eğitim ve Bilim. 42(190), 281-303.

Balcı, C. (2015). 8. Sınıf Öğrencilerine "Hücre Bölünmesi ve Kalıtım" Ünitesinin Öğretilmesinde Bilimsel Argümantasyon Temelli Öğrenme Sürecinin Etkisi. Adnan Menderes Üniversitesi. Fen Bilimleri Enstitüsü. Yayınlanmamıș Doktora Tezi. Aydın.

Beardsley, M. C. (1950), Practical Logic. Englewood Cliffs, NJ: Prentice-Hall.

*Berland, L. K. \& McNeill K. L. (2010). A Learning Progression for Scientific Argumentation: Understanding Student Work and Designing Supportive Instructional Contexts. Science Education. 94,765 -793.

*Berland, L. K., \& Reiser, B. J. (2009). Making sense of argumentation and explanation. Science Education, 93, 26-55.

Billig, M. (1989), The argumentative nature of holding strong views: a case study.European Journal of Social Psychology, 19, 203-223.

Boulter, C. J., \& Gilbert, J. K. (1995). Argument and science education. In P. J. Costello, \& S. Mitchell (Eds.), Competing and Consensual Voices (84-98). Clevedon, UK: Multilingual Matters.

Büyüköztürk, Ş., Kılıç Çakmak, E. Akgün, Ö. E., Karadeniz, Ș. \& Demirel, F. (2016). Bilimsel Araştırma Yöntemleri. Pegem akademi.

*Chang, S. N. \& Chui, M. H. (2008). Lakatos' Scientific Research Programmes as a Framework for Analysing Informal Argumentation about Socioscientific Issues. International Journal of Science Education. 30(13), 1753-1773.

*Chin, C. \& Teou, L-Y. (2009). Using Concept Cartoons in Formative Assessment: Scaffolding students' argumentation. International Journal of Science Education, 31 (10), 1307-1332.

*Clark, D. B., \& Sampson, V. D. (2007). Personally-seeded discussions to scaffold online argumentation. International Journal of Science Education, 29(3), 253-277.

*Dawson, V. M. \& Venville G. J. (2009) High-school Students' Informal Reasoning and Argumentation about Biotechnology: An indicator of scientific literacy? International Journal of Science Education, 31(11), 1421-1445.

Driver, R., Newton, P. \& Osborne, J. (2000). Establishing the norms of scientific argumentation in classrooms. Science Education, 84, 287-312.

Dung, P.M., Kowalsk,i R.A. \& Toni, F. (2006). Dialectic proof procedures for assumption-based, admissible argumentation. Artificial Intelligence 170, 114-159.

Duschl, R. A. (2007). Quality argumentation and epistemic criteria. In S. Erduran \& M. P. JiménezAleixandre (Eds.), Argumentation in science education (159-175). Dordrecht: Springer Netherlands.

Duschl, R. A., \& Osborne, J. (2002). Supporting and promoting argumentation discourse in science education. Studies in Science Education, 38(1), 39-72.

Duschl, R. A., Ellenbogen, K., \& Erduran, S. (1999). Middle school students' dialogic argumentation. In M. Komorek, H. Behrendt, H. Dahncke, R. Duit, W. Gräber, \& A. Kross (Eds.), Research in science education: Past, present and future; Proceedings of the Second International Conference of the European Science Education Research Association (420-422).

Erduran, S., \& Jiménez-Aleixandre, M. P. (2012). Argumentation in science education research: 
Perspectives from Europe. In D. Jorde, \& J. Dillon (Eds.), Science education research and practice in Europe: Retrospective and Prospective (pp. 253-289). Rotterdam, The Netherlands: Sense Publishers.

*Erduran, S., Simon, S., \& Osborne, J. (2004). TAPping into argumentation: Developments in the application of Toulmin's argument pattern for studying science discourse. Science Education, 88, 915-933.

Feteris, E. T. (2005). The Rational Reconstruction of Argumentation Referring to Consequences and Purposes in the Application of Legal Rules: A Pragma-Dialectical Perspective. Argumentation, 19, 459-470.

*Foong, C-C. \& Daniel, E. G. S. (2013). Students' Argumentation Skills across Two Socioscientific Issues in a Confucian Classroom: Is transfer possible? International Journal of Science Education, 35 (14), 2331-2355.

Fraenkel, J.R. \& N.E. Wallen (2000). How to Design and Evaluate Research in Education. (4th Edt.) Boston: McGraw-Hill.

*González-Howard M.; McNeill,K. L.; Marco-Bujosa, L.M.; Proctor, C. P. (2017) 'Does it answer the question or is it French fries?': an exploration of language supports for scientific argumentation, International Journal of Science Education, 39:5, 528-547, DOI: 10.1080/09500693.2017.1294785

Govier, T. (2010). A practical study of argument (7th ed.). Belmont: Wadsworth Cengage Learning.

Grasso, F., Cawsey, A. Jones, R. (2000). Dialectical argumentation to solve conflicts in advice giving: a case study in the promotion of healthy nutrition. International Journal Human-Computer Studies 53, 1077-1115.

*Grimes, P.; McDonald, S.; van Kampen, P. (2019). "We're getting somewhere": Development and implementation of a framework for the analysis of productive science discourse. Science Education. 103:5-36.

Gül, Ş. \& Sözbilir, M. (2015). Fen ve Matematik Eğitimi Alanında Gerçekleştirilen Ölçek Geliştirme Araştırmalarına Yönelik Tematik İçerik Analizi. Eğitim ve Bilim. 40 (178), 85 - 102.

Henson, K.T. (2001). Writing for professional journals: Paradoxes and promises. Phi Delta Kappan, 82, 765-768.

*Jiménez-Aleixandre, M. P., Rodriguez, A., \& Duschl, R. A. (2000). Doing the lesson or doing science: argument in high school genetics. Science Education, 84(6), 757-792.

Kaya, O. N. \& Kılıç Z. (2008). Etkin Bir Fen Öğretimi İçin Tartışmacı Söylev. Ahi Evran Üniversitesi Kırşehir Eğitim Fakültesi Dergisi, 9, 89-99.

*Kelly, G. J., Druker, S., \& Chen, C. (1998). Students' reasoning about electricity: Combining performance assessments with argumentation analysis. International Journal of Science Education, 20(7), 849871.

*Kim, H., \& Song, J. (2005). The features of peer argumentation in middle school students' scientific inquiry.

*Kolstø, S. D. (2007). Patterns in Students' Argumentation Confronted with a Risk-focused Socioscientific Issue. International Journal of Science Education, 28 (14), 1689-1716.

Kuhn, D. (1992). Thinking as argument. Harvard Educational Review, 62, 155-178.

Kuhn, D. (1993). Science argument: Implications for teaching and learning scientific thinking. Science Education, 77, 319-337.

*Kutluca, A.Y.; Aydın, A. (2017).Changes in Pre-service Science Teachers' Understandings After Being Involved in Explicit Nature of Science and Socioscientific Argumentation Processes. Science education, 26:637-668. DOI 10.1007/s11191-017-9919-x

Lawson, A. (2003). The nature and development of hypothetico-predictive argumentation with implications for science teaching. International Journal of Science Education, 25(11), 1387 - 1408.

*Liu, Q-T; Liu, B-W.; Lin, Y-R (2019). The influence of prior knowledge and collaborative online learning environment on students' argumentation in descriptive and theoretical scientific concept, International Journal of Science Education, 41:2, 165-187, DOI:10.1080/09500693.2018.1545100

*McNeill, K. L. (2011). Elementary students' views of explanation argumentation, and evidence, and their abilities to construct arguments over the school year. Journal of Research in Science Teaching, 48(7), 793-823.

Mercer, N., Wegerif, R., \& Dawes, L. (1999). Children's talk and the development of reasoning in the classroom. British Educational Research Journal, 25(1), 95-111.

Miles, M. B. \&Huberman, A. M. (1994). Qualitative data analysis. (2nd ed.). Thousand.

Milli Eğitim Bakanlı̆̆ı (2005). İlköğretim Fen ve Teknoloji Dersi (6, 7 ve 8. Sinıflar) Öğretim Programı. Ankara: MEB Yayınevi. 
Milli Eğitim Bakanlığı (2013) Fen Bilimleri Dersi Öğretim Programı (3.-8. sınıflar). Milli Ĕ̆itim Bakanlı̆̆ı Yayınları, Ankara.

Milli Eğitim Bakanlı̆̆ı. (2018). İlköğretim kurumları fen bilimler dersi (3, 4, 5, 6, 7 ve 8. Sınıflar) öğretim programı, Talim ve Terbiye Kurulu Başkanlığı, Ankara.

*Moon, A.; Stanford, C.; Cole, R.; Towns, M. (2017). Analysis of Inquiry Materials to Explain Complexity of Chemical Reasoning in Physical Chemistry Students' Argumentation. Journal of Research In Science Teaching 54(10), 1322-1346.

*Naylor, S., Keogh, B., \& Downing, B. (2007). Argumentation and primary science. Research in Science Education, 37(1), 17-39.

Next Generations Science Standards [NGGS] (2013) The Next Generation Science Standards-Executive Summary.http://www.nextgenscience.org/sites/ngss/files/Final\%20Release\%20NGSS\%20Front \%20Matter\%2-\%206.17.13\%20Update_0.pdf

*Nielsen, J. A. (2012). Science in Discussions: An Analysis of the Use of Science Content in Socioscientific Discussions. Science Education, 96, 428-456.

Nielsen, J. A. (2013). Dialectical Features of Students' Argumentation: A Critical Review of Argumentation Studies in Science Education. Research in Science Education, 43, 371-393.

*Nussbaum, E. M., Sinatra, G. M. \& Poliquin, A. (2008). Role of Epistemic Beliefs and Scientific Argumentation in Science Learning. Science Education, 30 (15), 1977-1999.

*Osborne, J F., Henderson, J. B., MacPherson, A., Szu, E., Wild, A. \& Yao S-Y. (2016). The Development and Validation of a Learning Progression for Argumentation in Science. Journal of Research in Science Teaching, 53 (6), 821-846.

*Osborne, J., Erduran, S., \& Simon, S. (2004). Enhancing the quality of argumentation in school *science. Journal of Research in Science Teaching, 41(10), 994-1020.

Özdem Yılmaz, Y. (2014). Science teachers' theory and pedagogy of argumentation in science education: design, implementation, and evaluation of a graduate course through educational design research. Yayınlanmamıș doktora tezi. ODTÜ İlköğretim bölümü. Ankara.

Özdem, Y., Ertepınar, H., Çakiroglu, J., \& Erduran, S. (2013). The nature of pre-service science teachers' argumentationin inquiry-oriented laboratory context. International Journal of Science Education, 35(15), 2559-2586.

*Pabuccu, A.; Erduran, S. (2017) Beyond rote learning in organic chemistry: the infusion and impact of argumentation in tertiary education, International Journal of Science Education, 39:9, 1154-1172, DOI: $10.1080 / 09500693.2017 .1319988$

Puvirajah, A., 2007. Exploring the quality and credibility of students' argumentation: teacher facilitated technology embedded scientific inquiry. Doctoral Dissertation, Wayne State University, USA.

Quinn, V. (1997). Critical Thinking in Young Minds. London: David Fulton. Research in Science Education, 36(3), 211-233.

*Ryu, S. \& Sandoval, W. A (2012). Improvements to Elementary Children's Epistemic Understanding From Sustained Argumentation. Science Education, 96, 488 - 526.

*Sadler, T. D., \& Donnelly, L. A. (2006). Socioscientific argumentation: The effects of content knowledge and morality. International Journal of Science Education, 28(12), 1463-1488.

*Sadler, T. D., \& Fowler, S. R. (2006). A threshold model of content knowledge transfer for socioscientific argumentation. Science Education, 90(6), 986-1004.

Scriven, M. (1976), Reasoning, New York: McGraw Hill.

TDK. (2014). Türkçe Sözlük. Ankara: TDK Yayınları.

Thomas, S. N. (1973). Practical Reasoning in Natural Language, Englewood Cliffs, NJ: Prentice-Hall.

Toulmin, S. E. (1958). The Uses of Argument. Cambridge: Cambridge University Press.

Tsai, C., \& Wen, M. L. (2005). Research and trends in science education from 1998 to 2002: a content analysis of publication in selected journals. International Journal of Science Education, 27(1), 3-14.

van Eemeren, F. H.\& Grootendorst, R. (1999). Developments in Argumentation Theory: Foundations if Argumentative Text Processing. Amsterdam: Amsterdam University Press.

van Eemeren, F. H., Grootendorst, R., Henkemans, F.S., Blair, J. A., Johnson, R. H., Krabbe, E. C. W., Plantin, C., Walton, D. N., Willard C. A., Woods, J., \& Zarefsky, D. (1996). Fundementals of Argumentation Theory: A Handbook of HistoricalBackgrounds and Contemporary Developments, Mahwah: Lawrence Erlbaum Associates.

van Eemeren, F. H., Houtlosser, P., \& Snoeck Henkemans, A. (2007). Argumentative indicators in discourse: A pragma-dialectical study. Dordrecht: Springer.

van Eemeren, F.H., Grootendorst, R. 2004. A Systematic Theory Of Argumentation. The Pragma-Dialected Approach. Cambridge University Pres, Cambridge. 
*Venville, G. J. \& Dawson V. M. (2010). The Impact of a Classroom Intervention on Grade 10 Students' Argumentation Skills, Informal Reasoning, and Conceptual Understanding of Science. Journal of Research In Science Teaching, 47 (8), 952-977.

Vygotsky, L.S. (1978). Mind in society. Cambridge, MA: MIT Press.

Walton, D. N. (1996). Argumentation Schemes for Presumptive Reasoning. Mahwah, NJ: Erlbaum

Walton, D. N. (1999). The new dialectic: A method of evaluating an argument used for some purpose in a given case. ProtoSociology, 13, 70-91.

Wassink, F. K. \& Sadi, Ö. (2016). Türkiye'de Fen Bilimleri Eğitimi Yönelimleri: 2005 ile 2014 Yılları Arası Bir İçerik Analizi. İlköğretim Online, 15(2), 594-614.

*Weng, W-Y; Lin, Y-R; She, H-C (2017) Scaffolding for argumentation in hypothetical and theoretical biology concepts, International Journal of Science Education, 39:7, 877-897, DOI: 10.1080/09500693.2017.1310409

*Yang, W-T., Lin, Y-R., She, H-C. \& Huang, K-Y. (2015). The Effects of Prior-knowledge and Online Learning Approaches on Students' Inquiry and Argumentation Abilities. International Journal of Science Education, 37 (10), 1564-1589.

*Yerrick, R. K. (2000). Lower Track Science Students' Argumentation and Open Inquiry Instruction. Journal of Research In Science Teaching, 37 (8), 807-838.

*Yun, S. M. \& Kim, H-B. (2015). Changes in Students' Participation and Small Group Norms in Scientific Argumentation. Research in Science Education, 45, 465-484.

*Zhu, M.; Lee, H-S.; Wang, T.; Liu O.L.; Belur, V.; Pallant, A. (2017) Investigating the impact of automated feedback on students' scientific argumentation, International Journal of Science Education, 39:12, 1648-1668, DOI: 10.1080/09500693.2017.1347303

Zohar, A., \& Nemet, F. (2002). Fostering students' knowledge and argumentation skills through dilemmas in human genetics. Journal of Research in Science Teaching, 39(1), 35-62. 
Appendix 1.Detailed comparison of rhetorical and dialectical studies in terms of aim, sample, subject area and data collection and analysis method themes

\begin{tabular}{|c|c|c|c|c|c|c|c|c|c|c|c|c|c|c|c|c|c|c|}
\hline & \multicolumn{5}{|c|}{ Aim of research } & \multicolumn{6}{|c|}{ Features of samples } & \multicolumn{4}{|c|}{ Subject of reseach } & \multicolumn{3}{|c|}{ Method } \\
\hline & 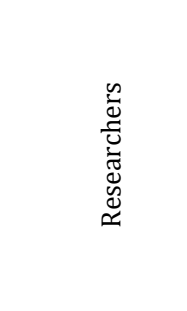 & 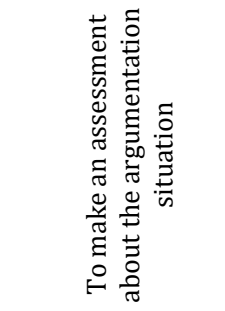 & 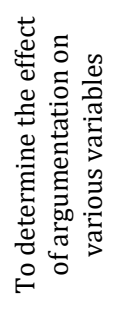 & 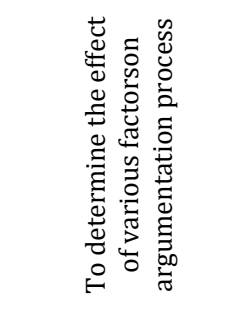 & 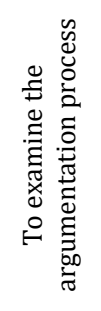 & 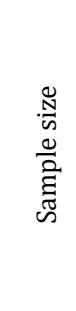 & 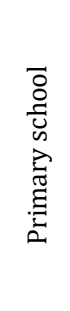 & 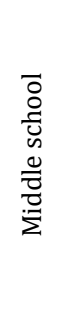 & 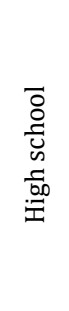 & 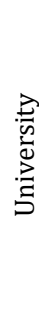 & 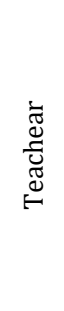 & $\frac{u}{n}$ & 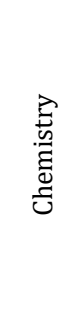 & $\begin{array}{l}\overrightarrow{00} \\
\frac{0}{0} \\
0\end{array}$ & 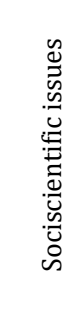 & 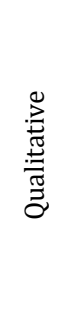 & 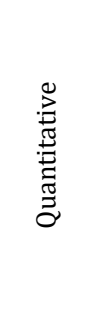 & $\stackrel{\vec{d}}{\stackrel{x}{\Sigma}}$ \\
\hline \multirow{5}{*}{ 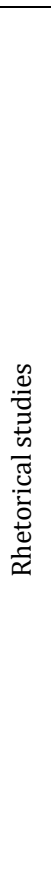 } & $\begin{array}{l}\text { Kelly, Druker } \\
\text { and Chen } \\
\text { (1998) }\end{array}$ & $\begin{array}{l}\text { To analyze the } \\
\text { argumentation of } \\
\text { students }\end{array}$ & & & & 20 & & & $\mathrm{X}$ & & & Electricity & & & & $\mathrm{X}$ & & \\
\hline & $\begin{array}{c}\text { Jimenez } \\
\text { Aleixandre, } \\
\text { Rodriguez } \\
\text { and } \\
\text { Duschl(2000) }\end{array}$ & $\begin{array}{l}\text { To analyze and } \\
\text { improve the } \\
\text { argumentation of } \\
\text { students }\end{array}$ & & & & 24 & & & $\mathrm{X}$ & & & & & Genetic & & $\mathrm{x}$ & & \\
\hline & $\begin{array}{l}\text { Yerrick } \\
(2000)\end{array}$ & & & $\begin{array}{l}\text { To investigate the } \\
\text { effect of inquiry } \\
\text { based science } \\
\text { teaching on } \\
\text { students' } \\
\text { argumentation } \\
\text { skills }\end{array}$ & & 5 & & & $\mathrm{X}$ & & & & & $\begin{array}{l}\text { Electricity } \\
\text { Matter } \\
\text { Sound }\end{array}$ & & $\mathrm{X}$ & & \\
\hline & $\begin{array}{l}\text { Erduran, } \\
\text { Simon and } \\
\text { Osborne } \\
(2004)\end{array}$ & & & $\begin{array}{l}\text { Using and } \\
\text { developing the } \\
\text { Toulmin model to } \\
\text { improve the } \\
\text { quality of } \\
\text { argumentation }\end{array}$ & & $12^{1}$ & & $\mathrm{x}$ & & & $\mathrm{x}$ & $\begin{array}{c}\text { Energy } \\
\text { Light } \\
\text { Acids and bases } \\
\text { Electricity }\end{array}$ & & & Zoo & & & $\mathrm{x}$ \\
\hline & $\begin{array}{c}\text { Osborne, } \\
\text { Erduran and } \\
\text { Simon (2004) }\end{array}$ & & & $\begin{array}{l}\text { To investigate the } \\
\text { effect of using } \\
\text { pedagogical } \\
\text { strategies by } \\
\text { teachers on } \\
\text { argumentation }\end{array}$ & & $12^{1}$ & & $\mathrm{X}$ & & & $\mathrm{X}$ & $\begin{array}{c}\text { Energy } \\
\text { Light } \\
\text { Acids and bases } \\
\text { Electricity }\end{array}$ & & & Zoo & & & $\mathrm{X}$ \\
\hline
\end{tabular}




\begin{tabular}{|c|c|c|c|c|c|c|c|c|c|c|c|c|}
\hline \multirow{7}{*}{ 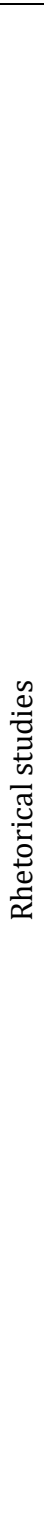 } & $\begin{array}{l}\text { Sadler and } \\
\text { Donnely } \\
\text { (2006) }\end{array}$ & & $\begin{array}{l}\text { To investigate the } \\
\text { contribution of } \\
\text { morality and } \\
\text { content } \\
\text { knowledge to } \\
\text { student } \\
\text { socioscientific } \\
\text { argumentation }\end{array}$ & & 48 & & $\mathrm{X}$ & & & Gene therapy & & $\mathrm{X}$ \\
\hline & $\begin{array}{l}\text { Sadler and } \\
\text { Fowler } \\
(2006)\end{array}$ & & & $\begin{array}{l}\text { To investigate how } \\
\text { students use their } \\
\text { scientific knowledge } \\
\text { for socioscientific } \\
\text { argumentation }\end{array}$ & 45 & & $\mathrm{X}$ & & & $\begin{array}{l}\text { Gene therapy } \\
\text { and cloning }\end{array}$ & & $\mathrm{X}$ \\
\hline & $\begin{array}{l}\text { Clark and } \\
\text { Sampson } \\
\text { (2007) }\end{array}$ & & $\begin{array}{l}\text { To determine the } \\
\text { effect of } \\
\text { asynchronous } \\
\text { discussions on } \\
\text { student } \\
\text { argumentation }\end{array}$ & & 84 & $\mathrm{X}$ & & $\begin{array}{l}\text { Heat- } \\
\text { temperature }\end{array}$ & & & & $\mathrm{X}$ \\
\hline & Kolstø, (2007) & & & $\begin{array}{l}\text { To investigate } \\
\text { students' opinions } \\
\text { about using } \\
\text { knowledge and } \\
\text { ethical values while } \\
\text { creating arguments } \\
\text { related to a } \\
\text { socioscientific } \\
\text { subject with risk }\end{array}$ & 22 & & & & 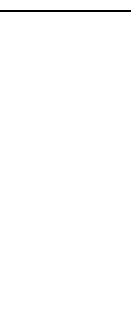 & $\begin{array}{l}\text { Local } \\
\text { construction } \\
\text { of new power } \\
\text { lines and the } \\
\text { possible } \\
\text { increased risk } \\
\text { of childhood } \\
\text { leukaemia }\end{array}$ & $\mathrm{X}$ & \\
\hline & $\begin{array}{l}\text { Chang and } \\
\text { Chui (2008) }\end{array}$ & $\begin{array}{l}\text { To compare the } \\
\text { argumentation } \\
\text { skills of students in } \\
\text { and out of the } \\
\text { science field using } \\
\text { the Lakatos } \\
\text { program }\end{array}$ & & & 70 & & $\mathrm{X}$ & & & $\begin{array}{l}\text { Genetically } \\
\text { modified } \\
\text { foods }\end{array}$ & & $\mathrm{X}$ \\
\hline & $\begin{array}{c}\text { Berland and } \\
\text { Reiser (2009) }\end{array}$ & $\begin{array}{l}\text { To analyze and } \\
\text { improve the } \\
\text { argumentation of } \\
\text { students }\end{array}$ & & & 53 & $\mathrm{x}$ & & & $\begin{array}{l}\text { Natural } \\
\text { selection }\end{array}$ & & $\mathrm{x}$ & \\
\hline & $\begin{array}{l}\text { Dawson and } \\
\text { Venville } \\
(2009)\end{array}$ & $\begin{array}{l}\text { To analyze the } \\
\text { argumentation of } \\
\text { students }\end{array}$ & & & 30 & & $\mathrm{x}$ & & & Biotechnology & $\mathrm{x}$ & \\
\hline
\end{tabular}




\begin{tabular}{|c|c|c|c|c|c|c|c|c|c|c|c|c|c|c|}
\hline \multirow{6}{*}{ 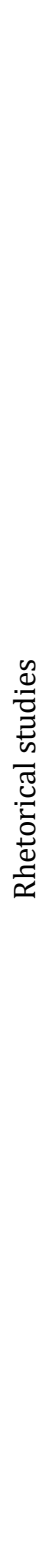 } & $\begin{array}{l}\text { Berland and } \\
\text { Mc Neill } \\
(2010)\end{array}$ & $\begin{array}{l}\text { Comparing oral } \\
\text { and written } \\
\text { argumentation } \\
\text { skills of different } \\
\text { grade level } \\
\text { students }\end{array}$ & & & $\mathrm{NC}^{2}$ & $\mathrm{X}$ & $\mathrm{X}$ & $X$ & $\begin{array}{l}\text { Force and } \\
\text { motion }\end{array}$ & & $\begin{array}{l}\text { Biodiversity } \\
\text { Adaptation } \\
\text { Natural } \\
\text { selection }\end{array}$ & & $\mathrm{X}$ & \\
\hline & $\begin{array}{l}\text { Venville and } \\
\text { Dawson } \\
(2010)\end{array}$ & & $\begin{array}{l}\text { To investigate } \\
\text { effect of } \\
\text { argumentation } \\
\text { on students' } \\
\text { informal } \\
\text { reasoning and } \\
\text { conceptual } \\
\text { changes related } \\
\text { to genetics }\end{array}$ & & 92 & & & $\mathrm{X}$ & 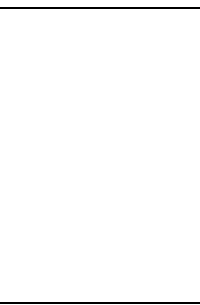 & & 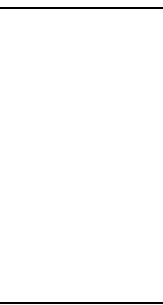 & $\begin{array}{c}\text { Genetic } \\
\text { designed baby }\end{array}$ & & $\mathrm{X}$ \\
\hline & $\begin{array}{l}\text { Mc Neill } \\
\text { (2011) }\end{array}$ & $\begin{array}{l}\text { To analyze and } \\
\text { develop students' } \\
\text { daily and scientific } \\
\text { arguments }\end{array}$ & & & 23 & & $\mathrm{X}$ & & & & Habitat & & & $\mathrm{X}$ \\
\hline & $\begin{array}{c}\text { Ryu and } \\
\text { Sandoval } \\
\text { (2012) }\end{array}$ & $\begin{array}{l}\text { To determine the } \\
\text { argument } \\
\text { development } \\
\text { levels of students } \\
\text { by applying the } \\
\text { argumentation } \\
\text { continuously }\end{array}$ & & & 21 & $\mathrm{X}$ & & & $\begin{array}{l}\text { Electricity and } \\
\text { magnetism }\end{array}$ & & $\begin{array}{l}\text { Climate } \\
\text { change }\end{array}$ & & & $\mathrm{X}$ \\
\hline & $\begin{array}{l}\text { Foong and } \\
\text { Daniel (2013) }\end{array}$ & & $\begin{array}{l}\text { To investigate } \\
\text { transferability of } \\
\text { students' } \\
\text { argumentation } \\
\text { skills from one } \\
\text { socioscientific } \\
\text { issue to another }\end{array}$ & & 35 & & $\mathrm{X}$ & & & & & $\begin{array}{l}\text { Genetically } \\
\text { modified } \\
\text { foods } \\
\text { Cutting } \\
\text { forests }\end{array}$ & $\mathrm{x}$ & \\
\hline & $\begin{array}{c}\text { Yang et al. } \\
\text { (2015) }\end{array}$ & & & $\begin{array}{l}\text { To investigate the } \\
\text { effect of individual } \\
\text { and social online } \\
\text { learning methods } \\
\text { on argumentation } \\
\text { skill }\end{array}$ & 118 & & $\mathrm{X}$ & & & $\begin{array}{l}\text { Classificatio } \\
\mathrm{n} \text { of } \\
\text { substances } \\
\text { Fire } \\
\text { prevention } \\
\text { Thermal } \\
\text { convection } \\
\text { Chemical } \\
\text { reaction } \\
\text { rates } \\
\text { Sound } \\
\text { waves } \\
\text { Mass } \\
\text { conservation }\end{array}$ & & & & $\mathrm{X}$ \\
\hline
\end{tabular}

73| KAHRAMAN \& KAYA 


\begin{tabular}{|c|c|c|c|c|c|c|c|c|c|c|c|c|c|c|c|c|}
\hline & $\begin{array}{l}\text { Osborne et al. } \\
\text { (2016) }\end{array}$ & & & & $\begin{array}{l}\text { To investigate how } \\
\text { to increase students' } \\
\text { argumentation skills }\end{array}$ & 803 & $X$ & X & & & $\begin{array}{l}\text { Structure of } \\
\text { matter }\end{array}$ & & & & & $\mathrm{X}$ \\
\hline & $\begin{array}{l}\text { Kutluca and } \\
\text { Aydın (2017) }\end{array}$ & & $\begin{array}{l}\text { To determine } \\
\text { effect of } \\
\text { argumentation on } \\
\text { students' } \\
\text { understanding of } \\
\text { the nature of } \\
\text { science }\end{array}$ & & & 56 & & & $\mathrm{X}$ & & & 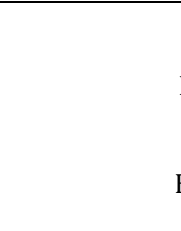 & $\begin{array}{c}\text { Nuclear } \\
\text { power plants } \\
\text { Hydroelectric } \\
\text { power plants } \\
\text { Fossil fuels } \\
\text { Biotechnology } \\
\text { Cloning }\end{array}$ & & & $\mathrm{X}$ \\
\hline & $\begin{array}{l}\text { Zhu, Lee, } \\
\text { Wang, Liu, } \\
\text { Belur and } \\
\text { Pallant } \\
\text { (2017) }\end{array}$ & & & $\begin{array}{l}\text { To examine effect } \\
\text { of automatic } \\
\text { feedback on } \\
\text { students' } \\
\text { argumentation } \\
\text { skills }\end{array}$ & & 183 & & $\mathrm{X}$ & & & & $\begin{array}{l}\text { Climate } \\
\text { change }\end{array}$ & & & $\mathrm{X}$ & \\
\hline & $\begin{array}{c}\text { Moon, } \\
\text { Stanford, Cole } \\
\text { and Towns } \\
\text { (2017) }\end{array}$ & & & $\begin{array}{l}\text { To investigate } \\
\text { effect of using } \\
\text { POGIL on } \\
\text { students' } \\
\text { argumentation }\end{array}$ & & 28 & & & $X$ & $\begin{array}{c}\text { Thermodynamic } \\
\text { s }\end{array}$ & & & & $\mathrm{X}$ & & \\
\hline 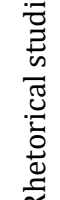 & $\begin{array}{l}\text { Pabuçcu and } \\
\text { Erduran } \\
(2017)\end{array}$ & & & & $\begin{array}{l}\text { To investigate how } \\
\text { preservis science } \\
\text { teacher make } \\
\text { argumentation in } \\
\text { organic chemistry } \\
\text { lesson }\end{array}$ & 89 & & & $\mathrm{X}$ & & $\begin{array}{c}\text { Organic } \\
\text { Chemistry } \\
\text { (conformatio } \\
\mathrm{n} \text { analysis ) }\end{array}$ & & & $\mathrm{X}$ & & \\
\hline & $\begin{array}{l}\text { Weng, Lin and } \\
\text { She (2017) }\end{array}$ & $\begin{array}{l}\text { To examine } \\
\text { students' } \\
\text { argumentation } \\
\text { quality }\end{array}$ & & & & 124 & $X$ & & & & & $\begin{array}{c}\text { Photosynthes } \\
\text { is } \\
\text { Genetic }\end{array}$ & & & $\mathrm{X}$ & \\
\hline & $\begin{array}{c}\text { Grimes, } \\
\text { McDonald and } \\
\text { van Kampen } \\
(2019)\end{array}$ & $\begin{array}{l}\text { To develop a } \\
\text { framework to } \\
\text { analyze the } \\
\text { argumentation } \\
\text { quality and to } \\
\text { implement this } \\
\text { framework } \\
\text { program }\end{array}$ & & & & 24 & & & $\mathrm{X}$ & Pressure & & & & $\mathrm{X}$ & & \\
\hline & $\begin{array}{l}\text { Liu, Liu and } \\
\text { Lin (2019) }\end{array}$ & & & $\begin{array}{l}\text { To determine the } \\
\text { effect of students' } \\
\text { prior knowledge } \\
\text { on monological } \\
\text { and collaborative } \\
\text { argumentation } \\
\text { process }\end{array}$ & & 138 & & $\mathrm{X}$ & & Conductors & $\begin{array}{l}\text { Reaction rate } \\
\text { Chemical } \\
\text { balance } \\
\text { Mass } \\
\text { conservation }\end{array}$ & Fermentation & & & & $\mathrm{X}$ \\
\hline
\end{tabular}




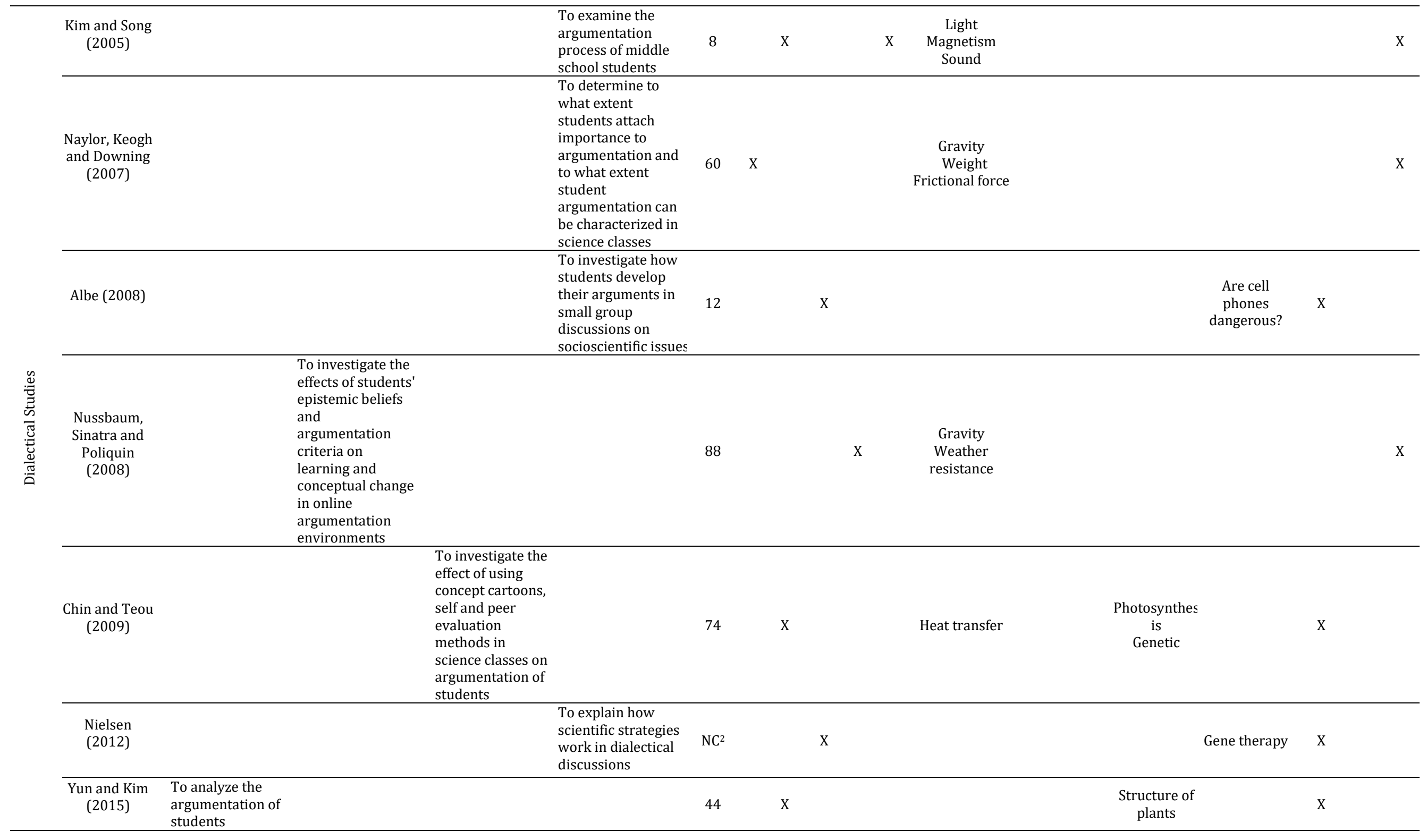

75| KAHRAMAN \& KAYA 


\begin{tabular}{|c|c|c|c|c|c|c|c|c|c|c|c|c|c|c|c|c|c|}
\hline $\begin{array}{c}\text { Gonzalaes- } \\
\text { Howard and } \\
\text { McNeill } \\
(2017)\end{array}$ & & & $\begin{array}{l}\text { To de } \\
\text { struct } \\
\text { langu } \\
\text { the te } \\
\text { includ } \\
\text { in the } \\
\text { argun } \\
\text { proce }\end{array}$ & & $\mathrm{NC}^{2}$ & & $\mathrm{X}$ & & & & & & $\begin{array}{l}\text { Microbiome } \\
\text { and } \\
\text { Metabolism }\end{array}$ & & $\mathrm{X}$ & & \\
\hline \multirow[t]{2}{*}{ Frequency } & 10 & 4 & 12 & 8 & & 3 & 14 & 13 & 6 & 3 & 13 & 4 & 12 & 12 & 16 & 2 & 16 \\
\hline & $\% 29$ & $\% 12$ & \%35 & $\% 23$ & & $\begin{array}{l}\% \\
9\end{array}$ & $\begin{array}{l}\% \\
41\end{array}$ & $\begin{array}{l}\% \\
38\end{array}$ & $\begin{array}{l}\% \\
1 \\
8\end{array}$ & $\begin{array}{c}\% \\
9\end{array}$ & $\% 38$ & $\% 12$ & $\% 35$ & $\% 35$ & $\begin{array}{l}\% \\
47\end{array}$ & $\begin{array}{c}\% \\
6\end{array}$ & $\begin{array}{l}\% \\
47\end{array}$ \\
\hline
\end{tabular}

${ }^{1}$ In the studies of Osborne, Erduran and Simon (2004) and Erduran, Simon and Osborne (2004), 12 teachers and students of these teachers were sampled. The number of students was not specified in the studies. Since there are 12 teachers and students in these studies, the total number of samples was coded as more than 200.

${ }^{2}$ Sample size in the research is not clear $(\mathrm{NC})$. 
Appendix 2. Detailed comparison of rhetorical and dialectical studies in terms of argumentation process and result themes

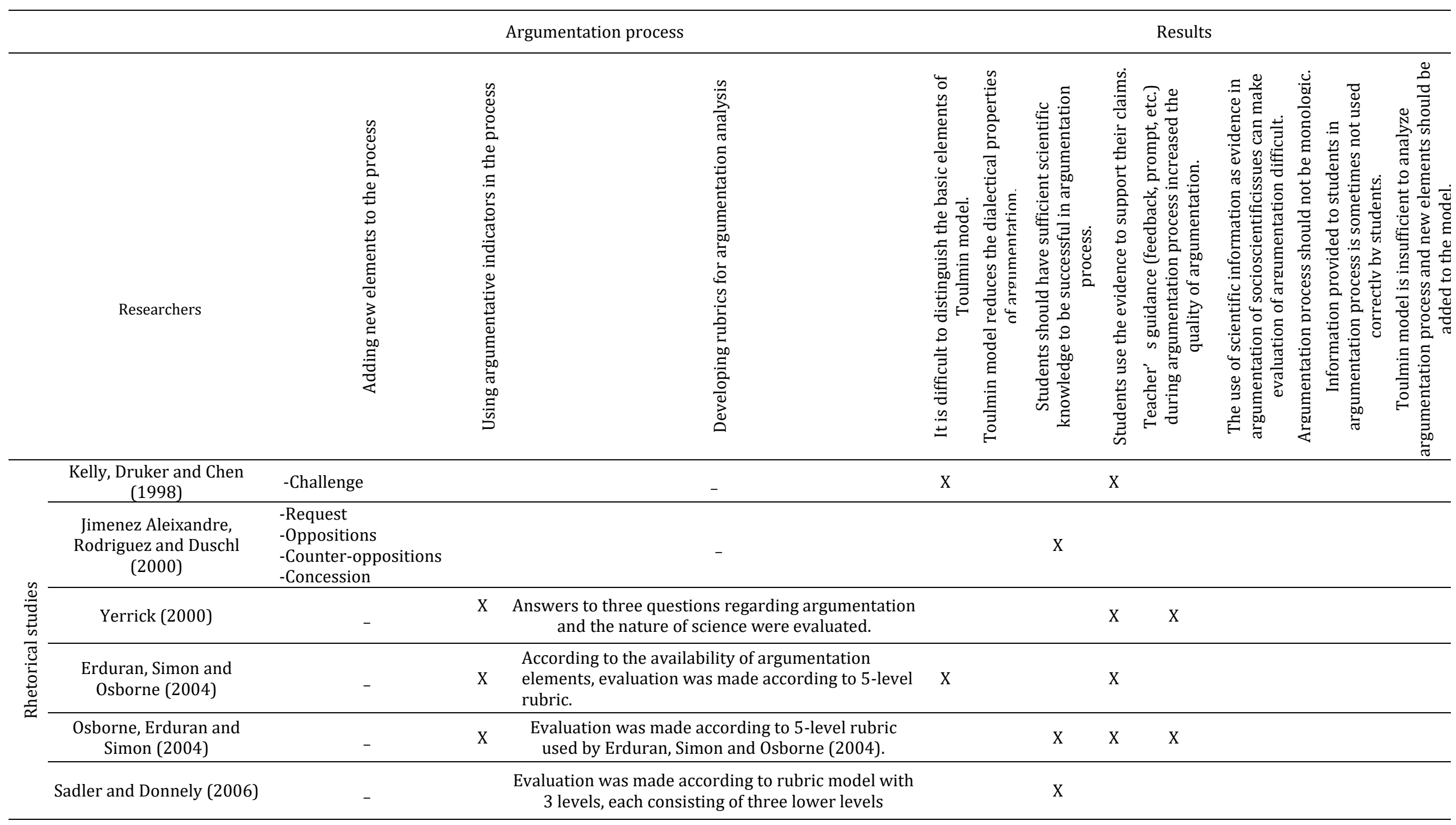

77| KAHRAMAN \& KAYA 


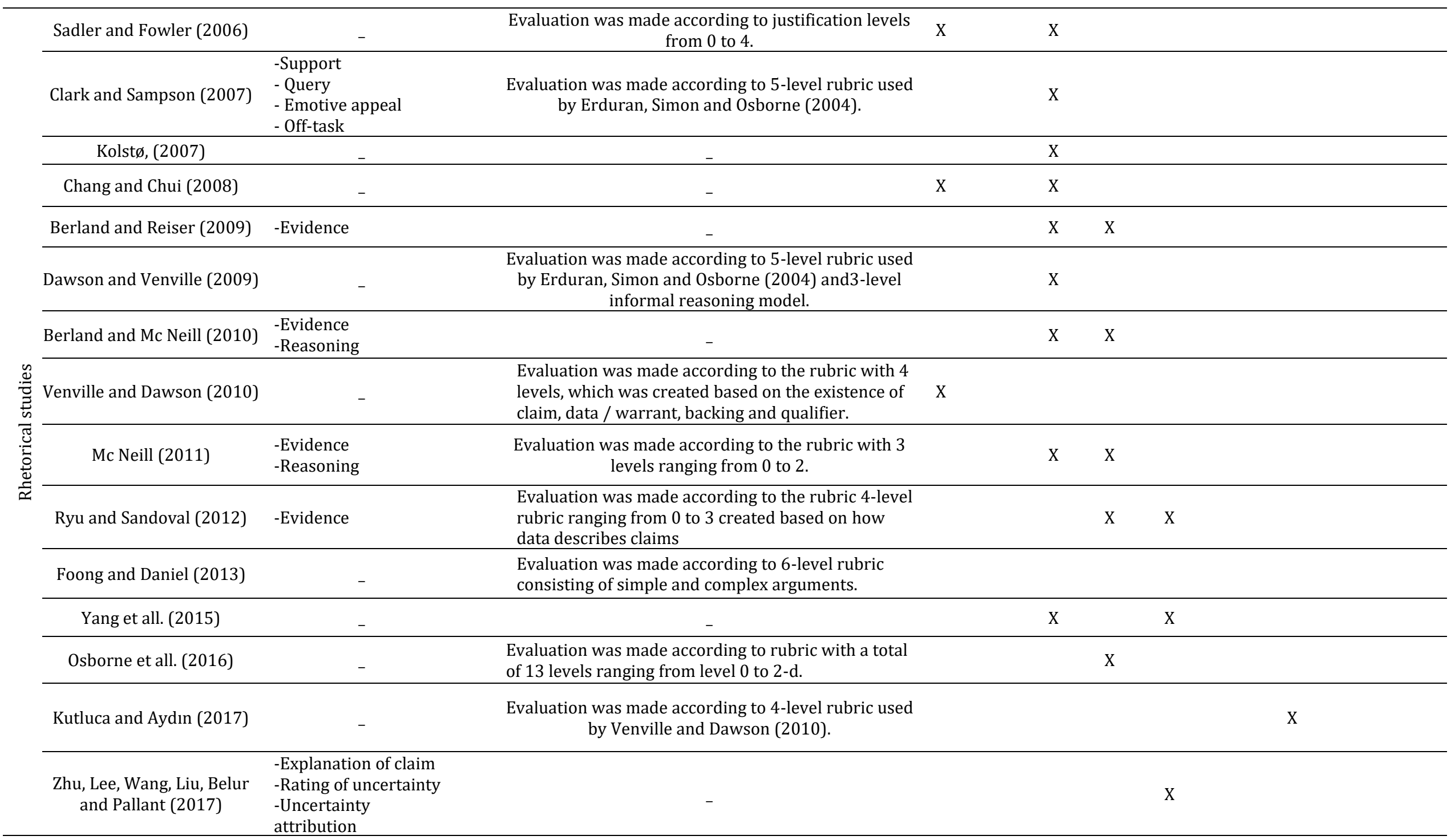




\begin{tabular}{|c|c|c|c|c|c|c|c|c|c|c|c|c|c|}
\hline \multirow{5}{*}{ 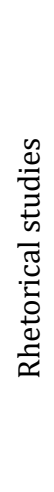 } & $\begin{array}{l}\text { Moon, Stanford, Cole and } \\
\text { Towns (2017) }\end{array}$ & - & & $\begin{array}{l}\text { Evaluation was made according to 4-level rubric } \\
\text { adapted from Sevian and Talanquer (2014). }\end{array}$ & & & & $\mathrm{X}$ & $\mathrm{X}$ & & & & \\
\hline & $\begin{array}{l}\text { Erduran and Pabuçcu } \\
\qquad(2017)\end{array}$ & - & $\mathrm{X}$ & $\begin{array}{l}\text { Evaluation was made according to } 5 \text {-level rubric used } \\
\text { by Erduran, Simon and Osborne (2004). }\end{array}$ & & & & $\mathrm{X}$ & & & & $\mathrm{X}$ & \\
\hline & Weng, Lin and She (2017) & - & & $\begin{array}{l}\text { Evaluation was made according to3-level rubric } \\
\text { adapted from Yeh and She (2010). }\end{array}$ & & & & & $\mathrm{X}$ & & & & \\
\hline & $\begin{array}{l}\text { Grimes, McDonald and van } \\
\text { Kampen (2019) }\end{array}$ & $\begin{array}{l}\text {-Prompt } \\
\text {-Clarification }\end{array}$ & & - & & & & & & & & & $\mathrm{X}$ \\
\hline & Liu, Liu and Lin (2019) & - & & $\begin{array}{c}\text { Evaluation was made according to } 3 \text {-level rubric used } \\
\text { by Weng, Lin ve She (2017). }\end{array}$ & & & $\mathrm{X}$ & & & & & & \\
\hline \multirow{9}{*}{ 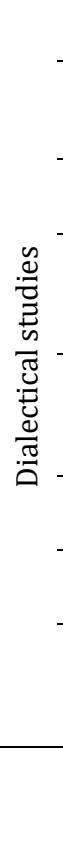 } & Kim and Song (2005) & - & & - & $\mathrm{X}$ & & & $\mathrm{X}$ & & & & & \\
\hline & $\begin{array}{l}\text { Naylor, Keogh and Downing } \\
\text { (2007) }\end{array}$ & - & & $\begin{array}{c}\text { Evaluation was made according to 7-level } \\
\text { Downing model. }\end{array}$ & $\mathrm{X}$ & & & $\mathrm{X}$ & & & & & \\
\hline & Albe (2008) & - & & - & & $\mathrm{X}$ & & & & & & & \\
\hline & $\begin{array}{l}\text { Nussbaum, Sinatra and } \\
\text { Poliquin (2008) }\end{array}$ & - & & $\begin{array}{c}\text { Evaluation was made according to } 5 \text {-level rubric } \\
\text { ranging from } 0-4 .\end{array}$ & & & & & $\mathrm{X}$ & & & & \\
\hline & Chin and Teou (2009) & - & $\mathrm{X}$ & $\begin{array}{c}\text { Evaluation was made according to 7-level } \\
\text { Downing model used by Naylor, Keogh and } \\
\text { Downing (2007). }\end{array}$ & $\mathrm{X}$ & & & & $\mathrm{X}$ & & & & \\
\hline & Nielsen (2012) & - & & - & $\mathrm{X}$ & $\mathrm{X}$ & & & & $\mathrm{X}$ & $\mathrm{X}$ & & \\
\hline & Yun and Kim (2015) & - & & Evaluation was made according to 11 -level rubric. & $\mathrm{X}$ & & & & & & & & \\
\hline & $\begin{array}{l}\text { Gonzales-Howard and } \\
\text { McNeill (2017) }\end{array}$ & - & & $\begin{array}{l}\text { Evaluation was made according to } 3 \text {-level rubric } \\
\text { model with stages } 0-1-2 \text {. }\end{array}$ & & & & & $\mathrm{X}$ & & & & \\
\hline & Frequency & $\begin{array}{c}9 \\
(\% 26)\end{array}$ & $\begin{array}{c}5 \\
(\% 1 \\
5)\end{array}$ & $\begin{array}{c}22 \\
(\% 65)\end{array}$ & $\begin{array}{c}10 \\
(\% 2 \\
9)\end{array}$ & $\begin{array}{l}2 \\
1 \\
\%\end{array}$ & $\begin{array}{c}13 \\
(\% 38)\end{array}$ & $\begin{array}{l}13 \\
(\% \\
38)\end{array}$ & $\begin{array}{c}10 \\
(\% 29)\end{array}$ & $\begin{array}{c}1 \\
(\% 3)\end{array}$ & $\begin{array}{c}2 \\
(\% \\
6)\end{array}$ & $\begin{array}{c}1 \\
(\% 3)\end{array}$ & $\begin{array}{c}1 \\
(\% 3)\end{array}$ \\
\hline
\end{tabular}

